Portland State University

PDXScholar

\title{
A Comparison of Object Dropping and Echoic Vocalizing as Response Modes to Pure Tone Stimuli Among Mentally Retarded Children
}

Elton L. Stewart

Portland State University

Follow this and additional works at: https://pdxscholar.library.pdx.edu/open_access_etds

Part of the Speech and Hearing Science Commons

Let us know how access to this document benefits you.

Recommended Citation

Stewart, Elton L., "A Comparison of Object Dropping and Echoic Vocalizing as Response Modes to Pure Tone Stimuli Among Mentally Retarded Children" (1970). Dissertations and Theses. Paper 705.

https://doi.org/10.15760/etd.705

This Thesis is brought to you for free and open access. It has been accepted for inclusion in Dissertations and Theses by an authorized administrator of PDXScholar. Please contact us if we can make this document more accessible: pdxscholar@pdx.edu. 


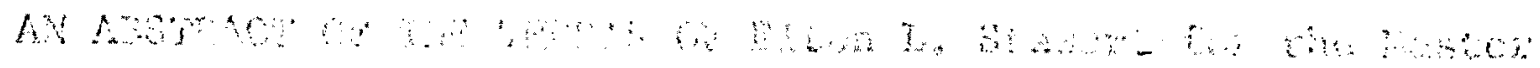

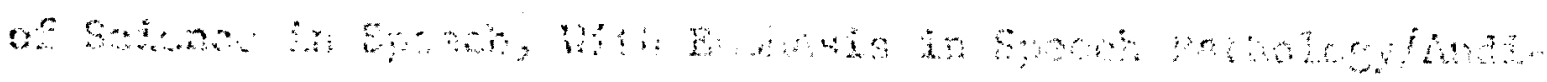

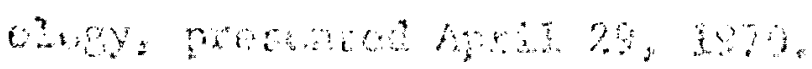

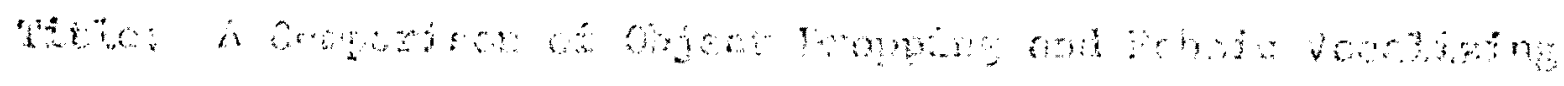

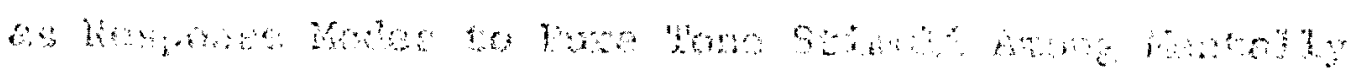

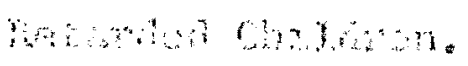

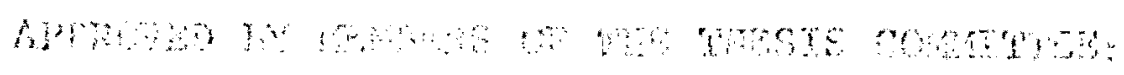
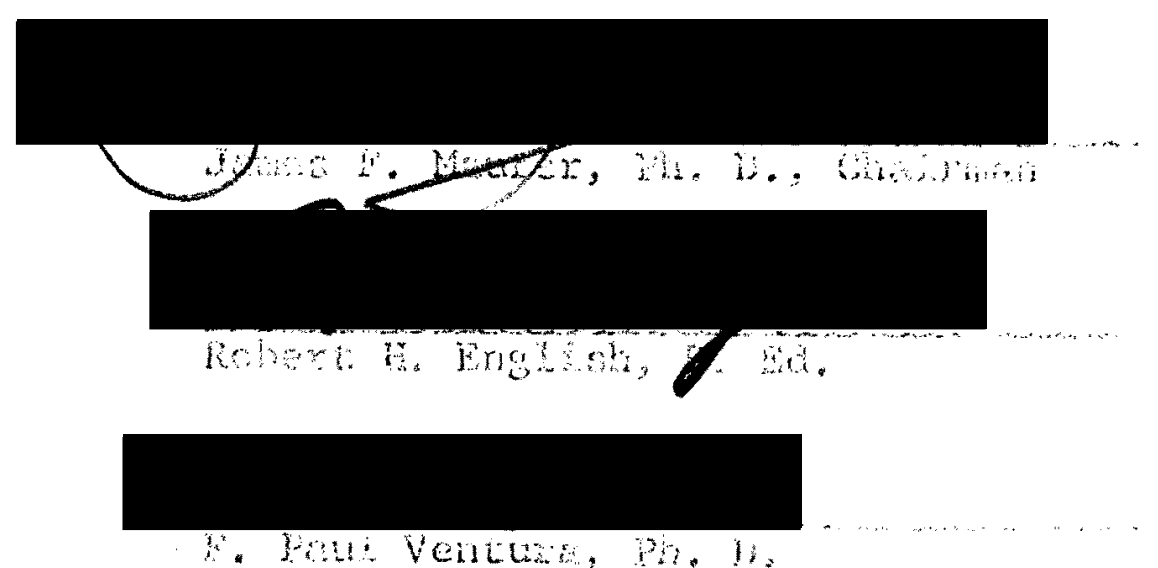

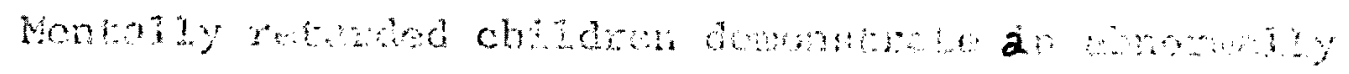

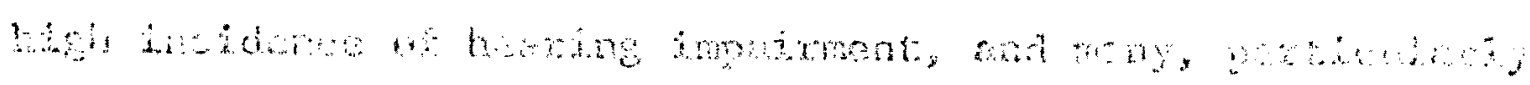

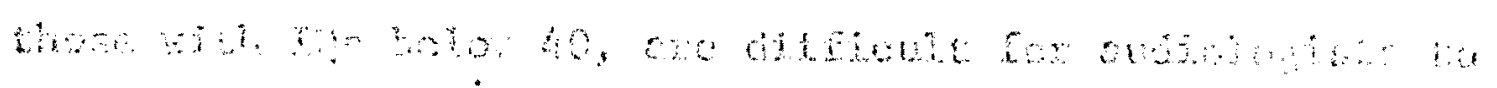

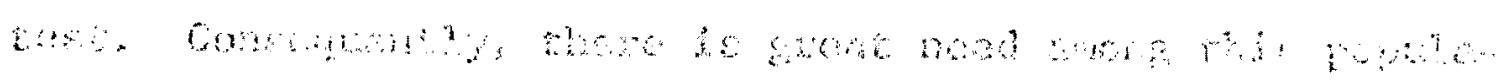

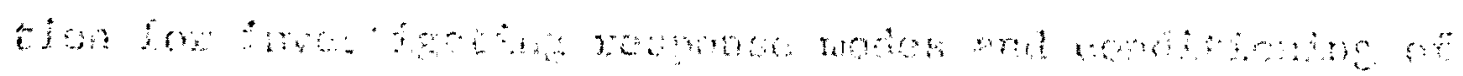

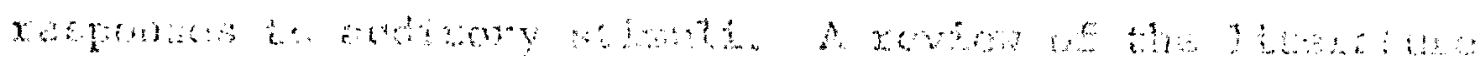

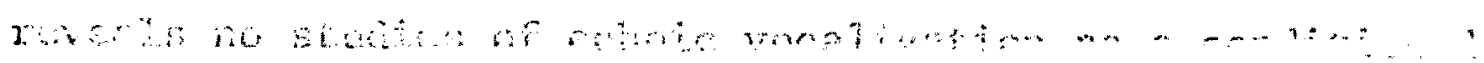




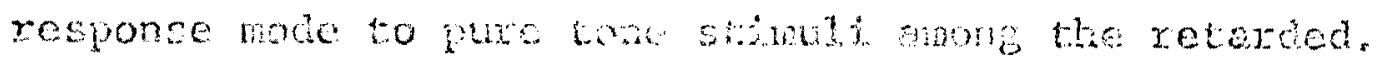

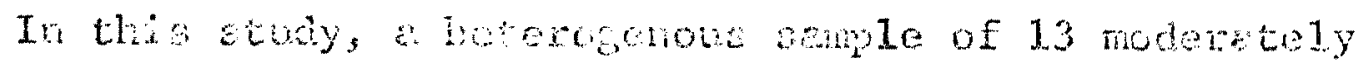
and severely retarom ditupen ronging in age from 7 years 7 wonths to 16 years 3 nowh vere compred on two rempone modes to suprethrestold pure Lowo signels of 500 and 4000 an: (1) cropping poker chips, and (2) echoic vocalization (bv). Ali subjects received hoth treatmonts but were divahi into Groups $A$ and $B$, the formox reciving Treatment one (objoct dropping) first, the later receiving preatment Too (EvT) rixst. Operant procedmes contind coctol and tengible rein forcenent in cech treotmen to ahteve stumb controt without specific verbal instrutions, EVR ineluded tro unmen? stagcs: (1) conditioning of jutetions bo the experinenter'c voulizations, usually /a/, and (2) conditioning of response

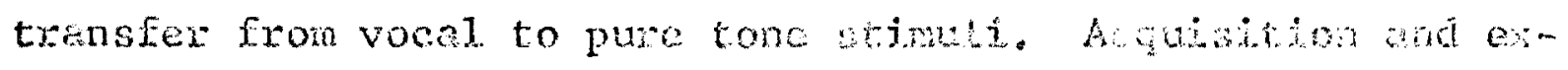
tinction to first 500, then 4000 ly proceeded sequentially within each treatrent. Acquisition criterion for vocel and pure tone stimuli nos eight conscutive responses. Extine. tion criterion was frilue to respond to zix out of eight

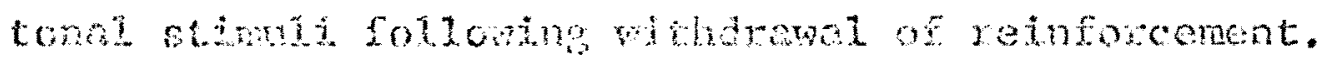

Eicoen of the 1.5 drithen aetiovod accuistition criterton tor both reponce moded, with coly three of the

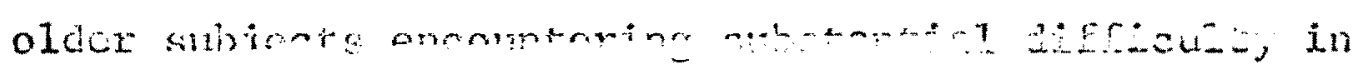




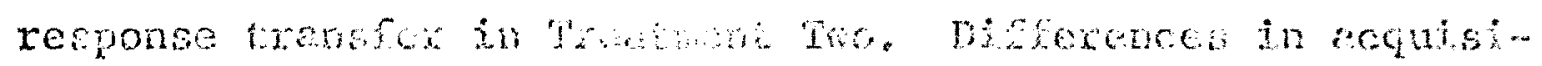

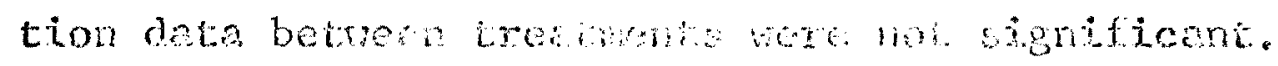

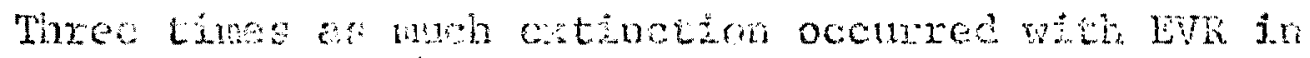

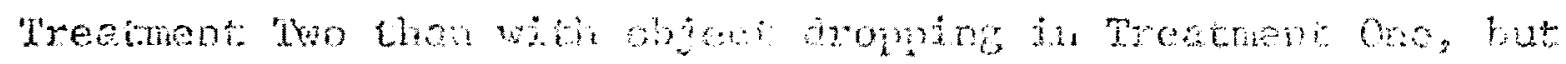

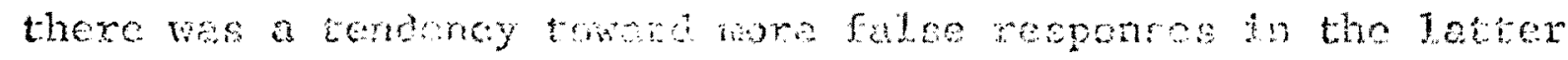

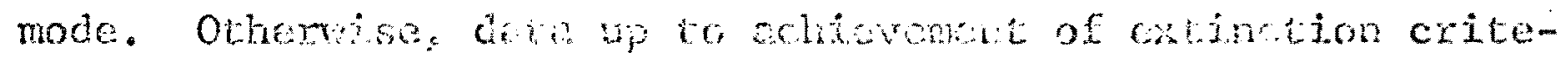

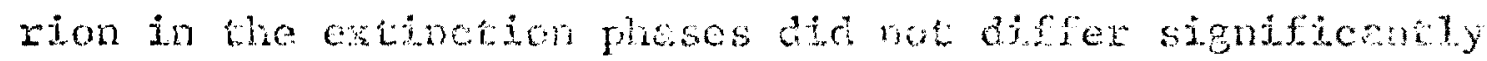
between treetrents.

Order of preventeting of treathent and fregueney of

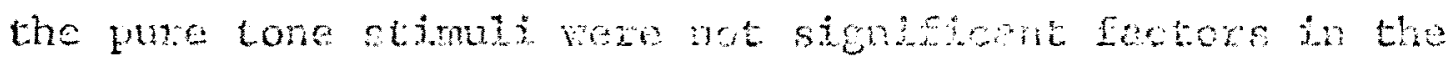
resulte.

It was concluded thet dopite subtentidy guethe

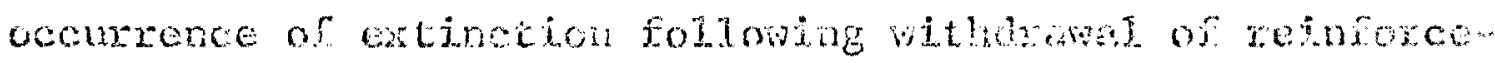
ment as compored with object dropping, echoic vocalization Lesponse hes ben shown to be en erentive, praction. rem sponse mode to supratheshold pure tone stimuli cuong lis chitareis in this sanple.

Ji nes recomended that further investigntion with EVR be dirented tmord: (1) the feasibijity of eliminoting respone trensfer by use of vestat assistance and drrect conditiontrg of EVR to juxe tones; (2) if response transfor

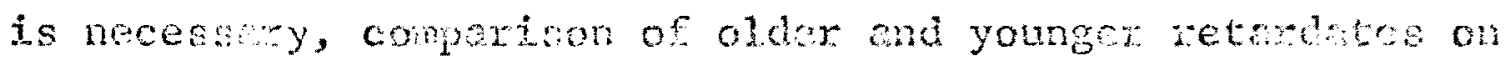

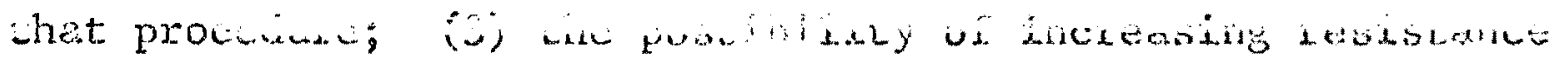




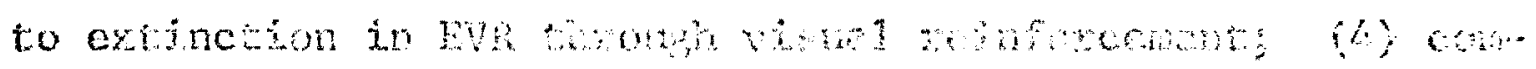

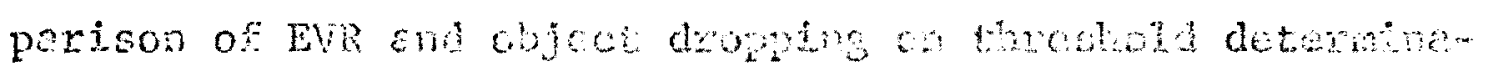

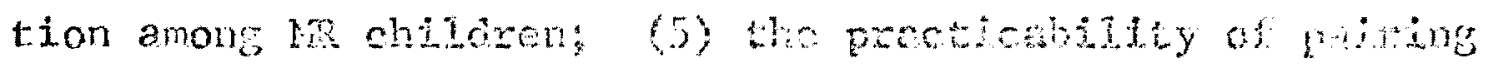

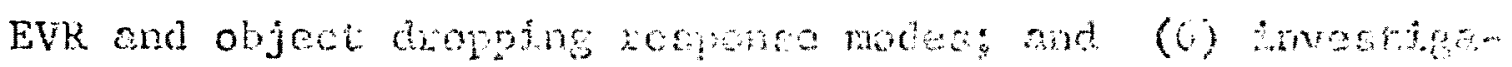

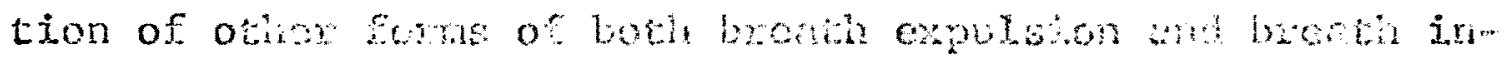
spirction as response modre to pure tone stimuls emong mentally retroded chingro, 
A COMPARTSO OF ORTECT DROPHTHO AND ECHOTC VOWUTZTXS

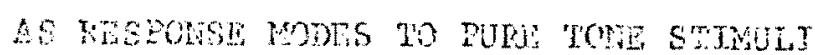

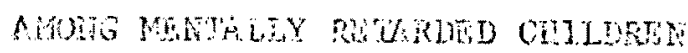

by

EITON $\because$ STEWART

A hests subujteo in partial fulfillnent of the requirements for the dagree of

\author{
MASTER OF SCIENCE in SPEECH \\ WITH EMPIASIS in \\ SWEECH PATHOLOOY/AUDIOLOGY \\ Prolarr! Stade universty \\ 1970
}




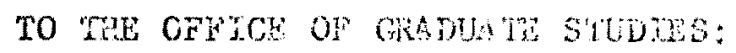

The members of the comitree appove the thesis of Elton L.

Stewart presented Apri1 29,1970

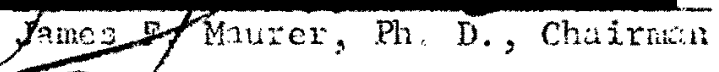

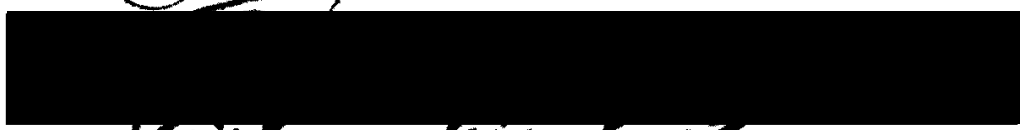

Robert H. English, H. Eg

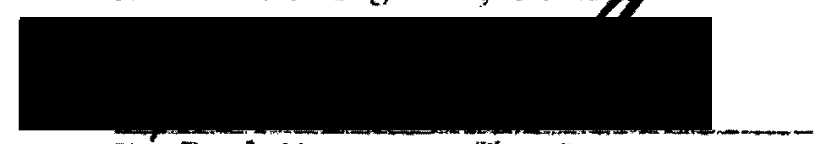

H. Pat. Vencura, Pi. D.

APPKONED:

C.MOA

Robert I. Casteal, Ph. D., Acting Co-chairman, Department of speech.

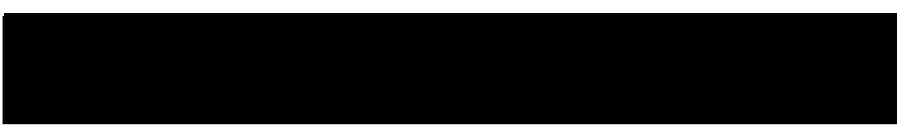

Patrick O. Marsh, Ph. D., Acting comchalman, Department of spech.

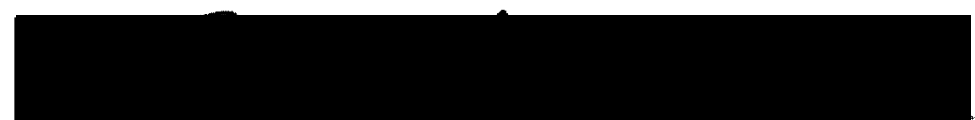

Franlet. Foberts, Ph. D., Acting jean of Graduate Studies

May 4,1970 
The writer wishes to ackuowledge the following for their special contributions to this study: Dr. Janes F. Maurer, my adviser for boin general content and statistical proedures, and an esteemed fricnd, whose perceptive critic sns and enduring sippont were crucial to the success of this endeavor.

Dr. Robert H. English and Dr. Paul Vencura, members of ny comittee and valued friends, whose long-term support ond guidance antedated anc nourished this project.

The staff members of the Speech Department of rortland state University, whose integrity and accomplishments, individual and collective, frovided not only a stimulating academic environment, but mojeis worthy of emulation as well.

Mrs. Doris Rosen, principal. of the Aloha Retarded Children's Center, and her dedicated staff, for their generous support and cooperation.

Tive dildren used as subjects, and of course, their parents, without whose cooperation this project could not have been accomplished. Miss Ciralene Aiders, my chief volunteer assistant, whose long hours spent in tabulating subject responses, timing test sequences, and attending to the needs of the children, were an invaluable contribution. 
Finally, T wisis to exress my sincere appeciation t:o my typist, Mrs. Margie Watts, whose patience for "cudjess" changes was seemingly limitless, and whose professional knowledge and competence in typing were a gratifying sonce of strength. 
TAEISE OF CONJENTS

PAGL

ACKNOWLEDGMENTS . . . . . . . . . . . . . . . . . . . iii

IIST OF TABLES. . . . . . . . . . . . . . . . . . . vii

LIST.OF FIGURES . . . . . . . . . . . . . . . . . . . viii

INTRODUCIION. . . . . . . . . . . . . . . . . . . . . 1

CHAPTER

I MISTORY OF THE PROBLEM ............... 4

II DESCRIPTION OF TIE FROBLEM . . . . . . . . . . 13

IIL METHOD . . . . . . . . . . . . . . . . 16

Subjects..................... 16

Test Room, Apparatus and Materials. . . . . 20

Selection of Stimuli............. 22

Selection of Reinforcements. . . . . . . 23

lrocedures.......................... 23

IV RESUlis. . . . . . . . . . . . . . . . . 27

General. . . . . ........... 2 . .

Ambysiz of the Data............. 31

Suming of kesules ............... 40

v DIscusston . . . . . . . . . . . . . . 43

VI SUMARY AN conctustons. . . . . . . . . . . . . 18

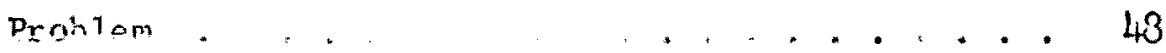


PACE

Method ................................. 48

Results. . . . . . . . . . . . . . 19

Conclusions. . . . . . . . . . . . . . 50

RETERENCES. . . . . . . . . . . . . . . . . . . 51

APPENDTCES

A: Definition of Techical Terms and Atbroviations. . 57

B: Formulac Used for Statistical Computatons . . . . 59 


\section{C.IST OF PABES}

TABLE

PAGF

I American Association For Mental Deficiency's

Classification of Mental Retardation. . . . . . 1

II Subject Data. . . . . . . . . . . . . . . . . 17

III Difficulty in Response Transfex Following Acquisition to Vocal stimulus............. 28

IV Subjects who Extinguished vs Subjects whe Did Not Extinguish...................... 30

$\mathrm{V}$ Comparison of Means for Order of Presentation . . . . 32

VI Comparison of Mealis for 500 and $4000 \mathrm{~Hz}$ Fure I'ones. . . 33

VIJ Comparison of Means of Treatment One and Treatment Two.. 34

VIII Comparison of Means of MI Level III and MI Level IV . . . 33

IX Frequency of Positive and Negative Correlations Between IQs, MAs, CAs and Acquisition-Extinction Data. . . 39 


\section{LISE OY FIGURES}

FITURE:

뫁

I Experinental Controi Booth. . . . . . . . . . . 21

2 Comparisor of Cumulative Response Custes for Treatment

Oue and Treatnent Two During Futinction Phase for

$500 \mathrm{~Hz}$ Stinuli Following Withdratal of

keinforcemert................ 36

3 Comparison of Eunulative Response Curves for Treatment

Cne and Treatrent Two During Extinction Phase for

$4000 \mathrm{~Hz}$ Stimuli. Followilig Nithdrawal of

Reinforcement. . . ............. 3t 
$10 \mathrm{FOBUCHOH}$

The rest reliahle estinetes of the nunber of findividuals in thas

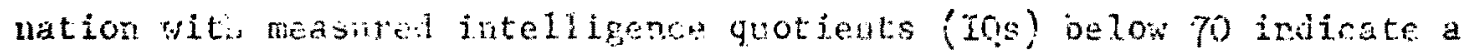

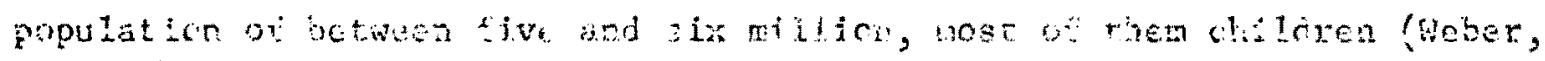
1967; Gardoex, 1967). In this study, they vil be categurzed aceording to the zystem adopted by the Amarican Asocintion for Mental La ficiency, from Heber (1959; revised 1961). (See Tablo i.)

THELE I

AAM CUASTFICATION OT MLTTAL RETAPMATOA

\begin{tabular}{|c|c|c|c|c|}
\hline \multirow{2}{*}{$\begin{array}{l}\text { Neasured } \\
\text { Inteili- } \\
\text { genor (IT) } \\
\text { Level of } \\
\text { Devilation }\end{array}$} & \multirow{2}{*}{ Description } & \multirow{2}{*}{ Si) Fange } & \multicolumn{2}{|c|}{ Io kange } \\
\hline & & & Enet & Wechsier \\
\hline I & Bordering & $=.01$ to -2.00 & $68-83$ & $70-8 \%$ \\
\hline 11 & Mild & -2.01 ז0 -3.00 & $52-67$ & $55-6 c$ \\
\hline$I I I$ & Moderate & -3.01 to -4.00 & $36-51$ & $40-54$ \\
\hline tv & Severe & $-4.01 \pm 0-5.00$ & $20-35$ & $25-39$ \\
\hline$v$ & Prozound & Beiow -5.00 & $\begin{array}{c}\text { Bel low } \\
20\end{array}$ & $\begin{array}{c}\text { Be jow } \\
25\end{array}$ \\
\hline
\end{tabular}

This population is rarticularly challenging to the audiologist for at leat four reason, hich cumblively povided the imperus ror the present ingestignason. 
(1) As a requisite to accurate differential diagnosis, a valid, roliable audiologic assessmint not oniy contributes vital information for appropriate medical and cducatinot direction, but nay challenge and even alter the validity of the "mentaliy retarded" (vik) label (iilywite and Brad1ey, 1969, p. 41).

(2) The amount of hearing impoiment in an individual retardate may be disproportionately handicapping, making its identification that much more important (Fisina and Lioyd, 1965b, p. 273; Kimmich, 1965, pp. 129-30; Fisch, 1968, p. 123; Lillyvhile and Bradley, p. 65 and p. 114 ). For example, a "moderate" loss nay cause the MR child greater difficulty in learning language hian would the same lose for a child of normal inte11igence.

(3) Data on incidence of hearing impaiment among MR children are remaxkable in several respects. There is ceneral agreement that the pexcentage is substantially higher than the 3 to 5 percent (O'Nejll and oyer, 1966, p. 293) of normal public school children reported with witd to severe losses, but in additior, the figures for MRs vary greatly, Birch and Matthews (1951) repoxted 2.5 to 1.8 times as mulh joss in 2 lir MRs 10 to 19 years of age as for norma1s. Lillywite and Bradleg (pp, 13-14) refer to an unpublished report on hearing testing in oregon of 2,235 entcable retardates in $1967-6 \%$ in which $17 \%$ had medically referrable losses, a figure approxirately five times the $3.3 \%$ found in that state's overall tommal sehool population that year. Schlanger and Gottsleben (1956) cite studies reporting that from 13 to $55.5 \%$ of this handicapped group evidence hearing loss. A more recent survey by Lloyd and Frisina (1965b) reports a range of 8 to $56 \%$. Incidence of hearing impairment anong MR childreo also departs from the trend among normal school. 
populations in its apparent increds with chrorological age (Schlanger and Gottsleben; Nudo, 1965; Vebs et a1., 1966).

(4) Many returded children are difficult to test, and a nubuer of reports have siated that conventionai hearing test procedures are not suitable for this population (Kodnan et a1., 1958; Neyexson, 1956 and 1965 ; Leach, 1965: wa1don, 1065: Hisch, 1968). 
CHA PTER Y

HISTORY OF THS PROSTEM

The essential concern of the avdiologist feced with the task of assessing MR children is to obiain adiometric threshold data which is valid and reliable. According to Lloyd and Frisina (1965b, p. 9), the wide variations in reforted incidence of hearing impairment among this population". . suggest a posstble lack of inter- and intra-test agreement and/or other ascessment problems." These problems have been associated with chareteristics of the child under test as well as a number of other factors.

Intelligence of the subject has been suggested as a variable by Lloyd and Frisina (1955b, p. 10). A study by Bradley, Evans and Worthington (1955) reported somewhat more test-retest variation among 30 retardates with IQ setween 30 and 50 than among an equal number with 10s between 50 and 79. Iloyd and Reid (1966), however; reported only a slight truad toward better test-retest agrement among retardates with IQs ranging from 40 to 75 as compared with lower levels. Lloyd; Reid and MoMonis (1968) found no relationship between size of pure tone testretest difference and $I Q$, and no significant difference between testretest reliability on consecutive days in comparing childrea in MI Levels IT, IJI, TV and V.

Atypical and divcree behaviors have been associated with variations in incidence data by Leach (1965) and Lloyd and Frisina (1965b), 


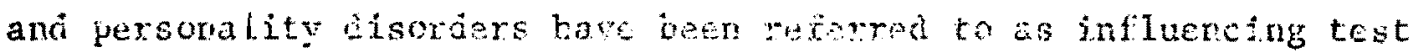
results by sehtanger and Gotsleban.

Kopatic (1965, p. 135) made the followirg statement in regard to testing hearing anong tivis popilation:

For purposes of validity, objectivity sud reliability cf rure tone aldionelry with the nencaliy candicapped, it: is recessary to obtain several audiogroms hatore the retarded subjects hearIns rapacity can be ascextained,

This was rate: challenged by L1oyd and Melrose (1966, 2 , 138) on the hasis of reliability data obtained in a study of foum gure tone and two speech threshold mosures:

When such rests are administered by a dualified audionghst, there appears to be no need to adgpt rouidil repat testing as a clinical procedure for mentally retarded bildren.

Frisina and Lloyd (1965b, 2. 272) claim thal audionetric testing an be accomplished at all levels of fetardation did recognize cricoria for tescability as dependent upon the skill of the audiologist and his methoda rather than on characteristics of the child. In another publication (uloyd and Frisina, 19658, p. 10), they state the following:

It is assumed that these children are testable when the appropriate methods are utilized and that the untestabiencss lies with the examiner and/or procedure and not necessarily with something inherent in the child.

Webi et 31., (1966) examined data frca 10 studies repoxting on hearing loss among over 5000 institutionalized MRs and found that incidence increased as a direct function of stringency of pass-fail criteria of the examiners, a variable also tontioned by Lloyd and Frisina (1965b, p. 10 ). The latter authors also refer to characteristios of the testirg environ.

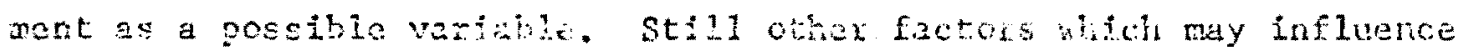

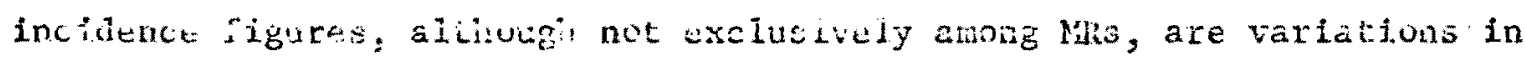


audiometer performance up to 10 ab at particular frequencies (Eagles and Doerfler, 1951), and differences befwen reports employing audiometers calibrated to American Standards bscoiation (ASA) reference levels of 1951 and the zero reference Ievels of the International organization for Standardization (ISO) adopted in this country in 1964.

The prevailing impression is that variations in incidence figures on hearing impairment anong retarded populations are indeed related in some degree to reliability and validity of test results, and that these, in turn, depend upon selection and skillful. jinplementation of appropriate tests and procedures for each patient.

A11 hearing tests involve two major classes of variables: first, the delivery of precise, quantifiable auditory stimuli; second, the identification of the patient's responses to these stimuli. The first category presents relatively lictle difficulty for the audiologist, although a frequent problem with retardates and young children is their injtial apprehension and rejection of the earphones. Generally, however, experienced clinicians will find conditioning procedures that will, in time, overcone this aversion.

It is within the second class of variabies that audiologists most frequently encounter serious difficulty in testing MR children; they often respond unprediccably and inconsistently if they respond at al1, even at suprathreshold icvels.

There are, of course, objective tests by which the examiner can circumvent some of the probloms associated with subjective techniques. Chiefly, these consist of the use of electroencephalography (EEG), and psychogalvanic skin response or reflex (PGSR or GSR) audiometry, the 
latter a iso referred to as efther electrodermal audometry (EnA) or. electrodermal response (FDR).

EEG has been described as a promising tectinique for difficult-toLest patients (Milier, de Schweinitz and Goetzinger, 1963, p. 149; 0'Ne:11 and cyer, $1.966, p .264)$, but it remajns in a developmental stage and requires equipment and skills not readily available to the average clinician. Garwood (1955, p. 238) states that EVG studies among the mertaily retarded are notably lacking in the literature, and Webb et 21 . (196h) describe the technique as "impractical" for that population.

GSR studies with the retarded are not yet conclusive. Fulton (1965, pp. 231-32) states that this cerhnique" . . can provide valid and reliable thresholds. . " with severely retarded individuals in some cases, but other reports on its applicability to this population describe "complete failure" (Waldon, 1965, p. 189), and "limited value" (Lamb and Graham, 1968, p. 727). Webo etal. (1954) state that GsR is no more effective with the mentally retarled than standard audiometry, and Lloyd and Reid (1966) cite comparisons with a modificd audometric tconique-conditioned orientation reflex ur iesponse (COR)--which found GSi the less reliable of the two.

Al1 other audiometric test methods--both standard and nodffied-mare essentially subjective tests and rely usa observation of the patient's responses to controlled sound stimuli. As such, they may be categorized as forms of behavioral audiometry. As defined by Goldstein (3962, p. 481), behavioral audionetry includes,

- . any overt response, whether it is an intentional raising of the hand when the tone is heard, a renetition of a word in a speech test; or an involuntary startle response of a child.

Frising (1963, p. 137) descatbes bihaviural audiometry in terms of 
reinforcement theory. From this standpoint, any subjective testing me. thod can be viewed as an operant paradigm in which stimulus control is achieved by selective rejnforcement of desired responses, Jeading to discriminative responsiveness by the subject to the auditory stimuli. Most standard and nodified pure tone tests with MR children require the child to respond with some type of identifiable notor behavior to each auditory stimulus. One exception is the use of "yes" responses as reported by Fale and Paterson (1954) with 100 boys in MI Leve1s I and II. Ordinarily, however, standard response modes consist of raising a hand or finger, or pressing a button in response to each discrete tonal stinulus. With higher level, cooperative retardates, verbal instructions may be sufficient to elieit the desired response behavior, but with lower leve 1 retardates, these may confuse more than they assist the subject. In these latter cases, expericnced audiologists rely more on gestural demonstration or actual nanipulation of the child's am or hand at the start, with use of social reinforcement such as "Good" or "Fine" to sustain response behavior.

A summary by Lloyd and Frisina (1965a) of 63 audiometric studies among the retarded indicates that standard audiometry has often been the method of choice for testing. This summary also demonstrates that the percontage of "untestables" has been rather high, ranging from $7 \%$ for $30 \mathrm{yRs}$ in MI Levels I to IV (Bradley, Evars and Worthington, 1955) to $45 \%$ for 20 children in MI Levels III and IV (Ryan and Stewart, 1965). Ifllywhite and Bradley (1969, pp, 112-1.3) state that the majority of re.tarded children can be testea by standard methods jf those appropriate to their mental deveiopment are chosen. Barr (1955) investigated use of pure tone audiometry among both normal and retarded pre-school children and 
reported conventional test prucedvas generally appifcable down to an Mi of 3.0 years, with flay audionetry sucessfill for about two-thirce of the childten in the MA range 2.5 to 3.0 years. He further reported that al1 pure. tone examinutions were uñsucesskul for children with "grave generai retardation and/or behavior problens" below a chronological age (CA) of 4.0 years.

Vartous modifications of standard procedures have been reported. Curry and Kurtarcek (1951) developed an ear-choice nethod requiring the child to pcint to the test ear as the signal was switched from side to side. Intensity of the signal was gradually lowered to thresiold as the clinician swept iron frequency to frequency. Loyd and Melrose (1966) used a modified ear-choice techitique in wich threshold was determined for one frequency at a time insteau of sweeping frequencies at each intensity level.

play audiometry may include the more corvencional hand-raising and ear-choice methods, but is more often thought of with reference to such motoric responses as dropping blocks, removing or inserting pegs on a pegboard, putting yines on a peg or removing them, striking an object such as a drum, etc. It has been hypothesized that repetition of such response medas has inherent reinforcing pruperties for the child (Lloyd, 1966, p. 131), but experienced cinjcians genergily use social reinforcement fin adfition in order to enlanee this exfect.

Visuai reinforcerents have ben used by audologiste with difficultte-test patients since 1930 (Eving). Fssentialyy, the nethod involves activation of a reinforcer such as a projected ficture or mechanical toy by the patient pressirg a button wher the cest signal. is present. Pressing the button when no sigital is present results in no reinforecment ind 
sometiries a delay in the next stinulus. The reinforcement schedule is typically $100 \%$, and social. reinforcenent is usually paired oith the visual. Lloyd (1965b) found his side-show technigue effective with many patients who were difticulc to test by conventional methods, but described it as not universally applicable. Weaver (1965) described the slide-show method as of primary utility with nomal young children, but applied the technique to two groups of retardates with respective mean IQs of 52 and 42 and found only one subject in the lower level group who could not be successfuliy conditioned and tested with that method.

Lloyd (1965) compared six threshold tests-hand raising, nodified ear-choice, play (block-dropping), and slide show for pure tores, and two speech reception tests (point-to-the-picture, say-the-word)--among 40 MI Leve, II and III childxen averaging 12 years, 6 months of age and corcluded that all of those methols were reliable if admintstered by a qualified audiologist. The play technique was slightly more reliable among the pure tone tests, and the two speech tests were reported slightiy nore reliable orerall than the four pure tone methots.

Other techniques which have been found useful with the retarded include forms of behavioral observation audiometry (BOA) such as conditioned orieutation response (COR) (Suzuki and Ogiba, 1961) and reflexive audionetry (Waldon, 1965). These are essentialiy outgrowths of infant scresning procedures, relying on identification of reflexive localizing or searching responses to sound stimuli. Fulton and Craham (1966) reported the technique as an effective screening device for the severely retardsd. Lloyd, spradin and reid (1968, p. 237) state that it was found mole successful with the moderately retarded than with lower levels. 
Because pure tomes are relatively irefficient stimuli. for both mentally retarded and romal young children (Ewing and Ewing, 1944; Froeschels and Beebe, 1946; Widim, 1965; Neruel, 1968), techniques have been devised with such civerse stiriult as animal sounds (Ryan and stewart, 1965 ), baby cries (Waldon, 1965), exclimations such as, "I'm here," and "Watch out" and non-speech sounds such as made by a cow, horn, rattle, etc. (Beedle et al., 1966). Each of these reports claimed significant advantages over use of pure tone stimuli with MR children. At best, however, they are gross screening Lechniques which can not differentiate between a patient's two ears and do not generally provide precise, diagnostically important threshold data for specific Erequencies.

Probabiy the most successful forms of behavioral audiometry with the mentally retarded are the techniques referred to as operant conditioning audiometry (OCA) or tangible reinforcement operant conditioning audiometry (TROCA) as reported by Spradlin and Lloyd (1965), Lloyd (1966), and Lloyd, spradiin and Reid (1968). Other reports on this type of testing have been made by Meyerson and Michael (1950) and by La Crosse and Bidlake (1964). The most detailed descripitions and apparently the most successful applications to MR children, particularly those in the lower MI levels, are found in the reports authored or co-authored by Lloyd. According to Lloyd, Spradlin and Reid (p. 239), TROCA procedures consist of five inter-related phases: (1) determining the most effective reinforcer; (2) injtial operant conditioning for pressing a large button in respone to an intense ( $70 \mathrm{~dB}$, ISO) warbied sound field tone; stimulus generalization to both lower intensity levels and different

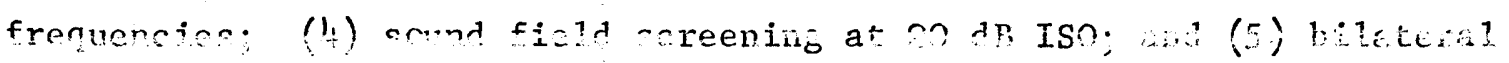
screening and threshold testing with earphones. The authors reportod 
(pp. 242-43) that they establisted staulus control using this procedure with 42 of 50 profoundly retarded children, and that of these, pure tone data were obtained on 39 which". . seemed valid in terms of reasonable audiometric configurations and agroment with other data such as otologic findings." Masking wa used vith both air and bone conduction tests. They state that TROCA could be adapted to obtain Bekesy, SISI, tone decay, Stenger, DL, and other specific audiologic information. The chief disadvantages appear to be the clinical time and number of sessions demanded. The profoundly retarded children they tested required between 4 and 50 ten- to twenty-ainute sessions.

It seems apparent, then, that no sirgle techisque for acquiring valid, reliable threshoid data among MR children has yet met with universal acceptance among audiologists. Frisina and Lloyd (1965b, p. 274) recognize this in the following statement:

There is great need, especially in Mr Levels IV and $V$, for systematically studying response modes and methods of conditioning for response to auditory stimuli.

It was with reference to this need that the following investigation was initiated. 


\section{CHAFTER·II}

\section{DESCRIPITON OF THE FROBLEM}

A review of the literature reveals no studies of echoic vocalization as a conaitioned response to pure tone stimuli. Nearly all applications of pure tone audionetry to MR children have used some form of motoric response, such as hand-raising, pointing, pressing a button, dropping blocks, etc. Verbal responses, of course, are a standard response mode in speech audiometry, and gross screening techriques such as BOA have used increase, decrease, or cessation of vocal activity, as well as humming and echoing us gross measures of response to a variety of speech and non-speech sound stimuli (Frisina and Lloyd, 1965b; p. 277). But apparently there have been no reports of systematic use of echoic vocalizations, defined here as any discrete, laryngeally-phonated sounds, as a specific mode of response to pure tones which is conditioned and brought under stimulus control.

It is well established that jnfants and young children's vocal behavior can be brought under stimulus control. Rheingold, Gewirtz and Ross (1959) demonstrated that vocal behavior could be very quickly modified in normal infants as young as three months. Horowitz (1963) has reported on effective reinforcenents and schedules for sustaining vocal behavior of MiR children. Many other studies (e.g., Kerr, Meyerson and Michae1, 1965 ; Salzinger et.al., 1965), have demonstrated success in shaping both vocal and verbal behaviors in children diagnosed as mentally retarded through use of roononse-contingent zeinferccment fropraming. There appoars to be no 1 inti to the applicability of such procedures in terms of Mi leveis, 
but reports by Bradley, Fvaiss and Worthington (1.955), Das (1961), and Fulton and Graham (1966) indjcate that conditjoning time is inversely related to MI leveI; i.e., lower level retardates are slower to condition. The primary purpose of this envestigation was to compare motor and echoic vocal responses (EVR) to guse tone stinul among MR children. Acquisition and extinction data for 500 and 4000 Hz suprathreshold signa $1 \mathrm{~s}$ were compared betwecn motor and echoic vocal responses.

The motor response used in this study was the dropping of poker chips into a pail. This is a type of response common to play audiometry and is very sinilar to the block-dropping method which Lloyd (1965a) reported as slightly more reliable for test-retest consistency than standard, ear-choice and slide-show techniques.

The echoic vocal response (EVR) included any discrete, laryngeallyphonated uttcrance which could be temporally identified as a response to the tonal stimulus. This response eategory was defined broadly to include practically any non-vegetative vocal activity, since the specific type used by a child might depend upon (1) his repertoire of vacal behaviors, (2) the particular vocalization brought under stimulus control in the operant paradigm, and (3) variability among vocal responses from event to event. Thus, for one child, guttural, vowel-like grunts might be acceptable; for another, a particular word or phrase or a variety of verbal utterances might serve equally well. The variability of possible responses within this class was hot deemed critice1, since it was primarily the temporal relationship of the response to the stimulus which would determine validity.

It was felt that the essential criteria for identification and acceptance of classes of responses, whether motor or vocal, were, 
that the auditory stimulus become Aiscriminative for responding, i.e., become a discriminative stimulus ( $S$ ); and (2) that absence of the tonal stimulus becone a neutral stimulus $\left(s^{\Delta}\right)$. Assuming an effective reinforcer for each child, these criteria were felt to be both achievabie and compatible with established reinforcement principles.

The problem to be investigated is stated in the following two hypotheses:

(1) A heterogenous sample of moderately and severely mentally retarded children will demonstrate significant differences in acquisition data obtained for echoic vocal responses to suprathreshold pure tone stimuli as compared with similar data for motor responses (object dropping) to the same stimuli.

(2) A hetecogenous sample of moderately and severely mentally retarded children will demonstrate significant differences in extinction data obtained for echoic vocal responses to suprathreshold pure tone stimu11 as compared with similar data for motox responses (object dropping) to the same stimuli.

In addition, the following questions were felt to be of intarest:

(1) Is echoic vocalization a practical response mode to pure tone signals for mentally retarded children? Is this a modification which might be used alternatively and more or less equally well as compaced with standard and play response modes?

(2) What are the specific advantages or disadvartages which might be expected in application of this response mode to mentally retarded subjects?

(3) What are the intications $2 \%$ further research? 
CHA PIER ITI

METHOD

\section{SUBJECTS}

Fourteen children, 6 boys and 8 girls, were initially selected from an enrollment of 24 at the Retarded Children's Center in Aloha, Oregon. of the original 14, one 9-year-old boy failed to achieve criterion for either the motor or echoic vocal response (EVR) modes and was dropped from the study. Another boy, 15-years old, achieved criterion on the motor tasks but fajled to reach the criterion on tasks involving EVR. In addition, one 13 -year-old girl reached criterion on all tests except those Involving motor responses to $4000 \mathrm{~Hz}$ signals. Thus, the total $\mathrm{N}$ for di.Eferent statistical treatments ranged from 13 to 11 . Criteria for those subjects included in the study (Table II) encompassed the following:

\section{Menta1 Age}

MAs between 2.0 and 5.0 were sought for the following reasons: Children with MAs above 5.0 years are not considered genera11y difficult to test; standand hand-raisiag, ear-chojce or play techniques are usually effective. (2) Children below an IIA level of 2.0 years are most often quite difficult to test by any conventional methods and require greater clinical time to condition. The limited scope of this investigation did not justify inclusion of subjects with extremely low MAs.

Unfortunately, as is often the case with trainable MRs, precise, recent psychometric data mere not available for all subjects. MAs based 
TABLE II

SUBJECT DATA

\begin{tabular}{|c|c|c|c|c|c|c|c|}
\hline subject & Group & Sex & $\begin{array}{c}\text { CA } \\
\text { Yr. Mo. }\end{array}$ & $\begin{array}{c}\text { MA } \\
\text { Yr. Mo. }\end{array}$ & $S B$ IQ & MI Leve1 & $\begin{array}{c}\text { Diagnostic } \\
\text { Label }\end{array}$ \\
\hline $\mathrm{DB}$ & $\mathrm{A}$ & F & $10-10$ & $2-9$ & 35 & IV & \\
\hline L.H & A & $F$ & $13-5$ & $3-9$ & 38 & I.II & \\
\hline $\mathrm{CB}$ & $\mathrm{A}$ & $M$ & $14-4$ & $\cdots$ & 34 & IV & \\
\hline DM & A & $M$ & $15-0$ & $-\cdots$ & 37 & III & \\
\hline$M D$ & A. & $M$ & $11-4$ & $-\cdots$ & $\cdot--$ & -- & "Mod." MR \\
\hline DS & A & $M$ & $7-7$ & -- & -- & -- & "Sev." MR \\
\hline $\mathrm{CB}$ & A & $\mathrm{F}$ & $7-7$ & $2-11$ & -- & $\cdots$ & "Mod." MR \\
\hline$L K$ & B & $M$ & $12-10$ & $\cdots$ & 31 & IV & \\
\hline I.L & B & F & $12-3$ & $2-2$ & 30 & IV & \\
\hline EH & B & $\mathrm{F}$ & $8-5$ & $3-3$ & 48 & III & \\
\hline$L D$ & B & $\mathrm{F}$ & $7-3$ & $2 \cdot 10$ & 43 & III & \\
\hline SH & B & $\mathrm{F}$ & $16-3$ & $3-8$ & 49 & III & \\
\hline $\mathrm{CC}$ & B & $\mathrm{F}$ & $11-3$ & -- & -- & -- & "Sev." MR \\
\hline
\end{tabular}


on the Stanford-Binet Intelligence Scele were available on seven of the subjects and ranged from 2 years, 2 months to 3 years, 9 months, with a mean of 3 years, 1 month. No specific MA data were available on the remalning six children. However, three of the latter had been assigred Binet IQs which were within the "moderate" and "severe" categories of the AAMD (Table 1) and the remaining three had been medically diagnosed as either "moderately severe retardation" (one case) or "severe retardation" (two cases). Thus, croup A contained three subjects whose mean MA was 3 years, 2 months, and four whose MAs were unspecified. Group B consisted of four subjects whose mean. MA was 3 years, $l$ month and two whose MAs were not specified.

\section{Inte11igence}

- So far as possible, children were selected trom the IQ range 20 to 51 on the Revised Stanfort-Binet. This range encompasses MI Leveis III and IV, "moderate" to "severe" retardation. spradlin (1967) has stated that qualified audiologists have been able to accomplish pure tone testing on most children with IQs of 40 or above, corresponding roughly with the lower limits of the moderate range of retardation, and Frisina and Lloyd (1965a) recognize the levels below this as most challenging for the clinical audiologist.' Thus the range selected permits comparison of the two response modes among some children in MI Level III who may be relatively easy to condition and those individuals in MI Level IV who may be difficult to test.

Recorded Ins available for nine subjects ranged from 30 to 49 , with a mean of 38 . The remsining four were unrecorded except in terms of general range or medical diagnosis. Thus, Group A consisted of four subjects 
with measured scores ranging from 34 to 38 and a mean of 36 . Two of the remaining three in Grolip A had a medical. diagnosis of "moderate" retardation; the third had heen diagnoed as "severe" retardation. Group B was made up of five individuals ranging from 30 to itg in Binet IQs, with a mean of 40 , and one subject with ait unspecified IQ who had been diagnosed as "severe" in retardation.

\section{Chronological Age}

$\mathrm{CA}$ is not of particular importance in a study comparing the same subjects on two different measures. An age range from 7 to 18 years was arbitrarily selected to allow greater generalization of projected results to schoo1-age MR populations. In addition, it was felt that comparison of response behaviors between children with similar MAs but differing in CAs would be of interest.

The 13 subjects included in this study ranged from 7.25 years to 16.25 years with a mean $C A$ of 11.38 years. The six Group A subjects ranged from 7.6 to 15.0 years, with a mean $\mathrm{CA}$ of 10.8 years. The six subjects in Group B ranged in age from 7.25 to 16.25 years with a mean CA of 11.4 years.

\section{Physiologic and Sensory Factors}

Children with handicapping neuronuscular involvement, specific. brain damage, or gross sensory impairment were excluded from consideration because of the likelihood of special difficulties in responding to the testing procedures. This study particularly required that each child have auditory acuity in his test ear which would permit responses to 500 and $4000 \mathrm{~Hz}$ air-conducted pure tones delivered by earphone of $70 \mathrm{HB}$ HT. Therefore, as a precautionary mcasure, a screening criterion of $20 \mathrm{AB}$ 
below this level was established so that only children with pure tone thresholds of $50 \mathrm{~dB}$ or better in the cest car at those frequencies were selected.

II. TFST ROOM, APPARATUS, AND MATERTALS

The experimental progran was conducted in a special education room of a public elementary school during a sumner pexiod when classes were not in session. This provided an environment which was relatively free from distractions. Included were three chairs (one for the experimenter, one for an assistant recording data, and one for the subject), an experimental control booth (Figure 1), a recently calibrated Majco MA-16 portable audiometer, 100 plastic poker chips in a plastic pail, a tin pail, and supplies of five different nutrient reinforcers.

Ambient noise level in this environment was periodically monitored with a General Radio Company Type 2203 sound level meter and found to vary within a range of 42 to $58 \mathrm{~dB} S P L$ on the $\mathrm{C}$ scale (ASA, 195.1). According to Hirsh (1952, p. I64) the typical earphone cushion attenuates about $20 \mathrm{~dB}$ of externaliy produced noise. The same source (p. 163) defines audiometric "quiet" as an environment in which the overall SPL of a flat-spectrum noise does not exceed $30 \mathrm{~dB}$ (ASA). This accounts for his conclusion that 40 to $50 \mathrm{~dB}$ of such noise is permissible for pure tone threshold testing. ' Since air-conducted test signals of 500 and $4000 \mathrm{~Hz}$ in this experiment were delivered by earphone at suprathreshold levels only (70 dE ML), the possibilities of amient noise in the 42 to $58 \mathrm{~dB}$ range effectively masking these tones were remote. 


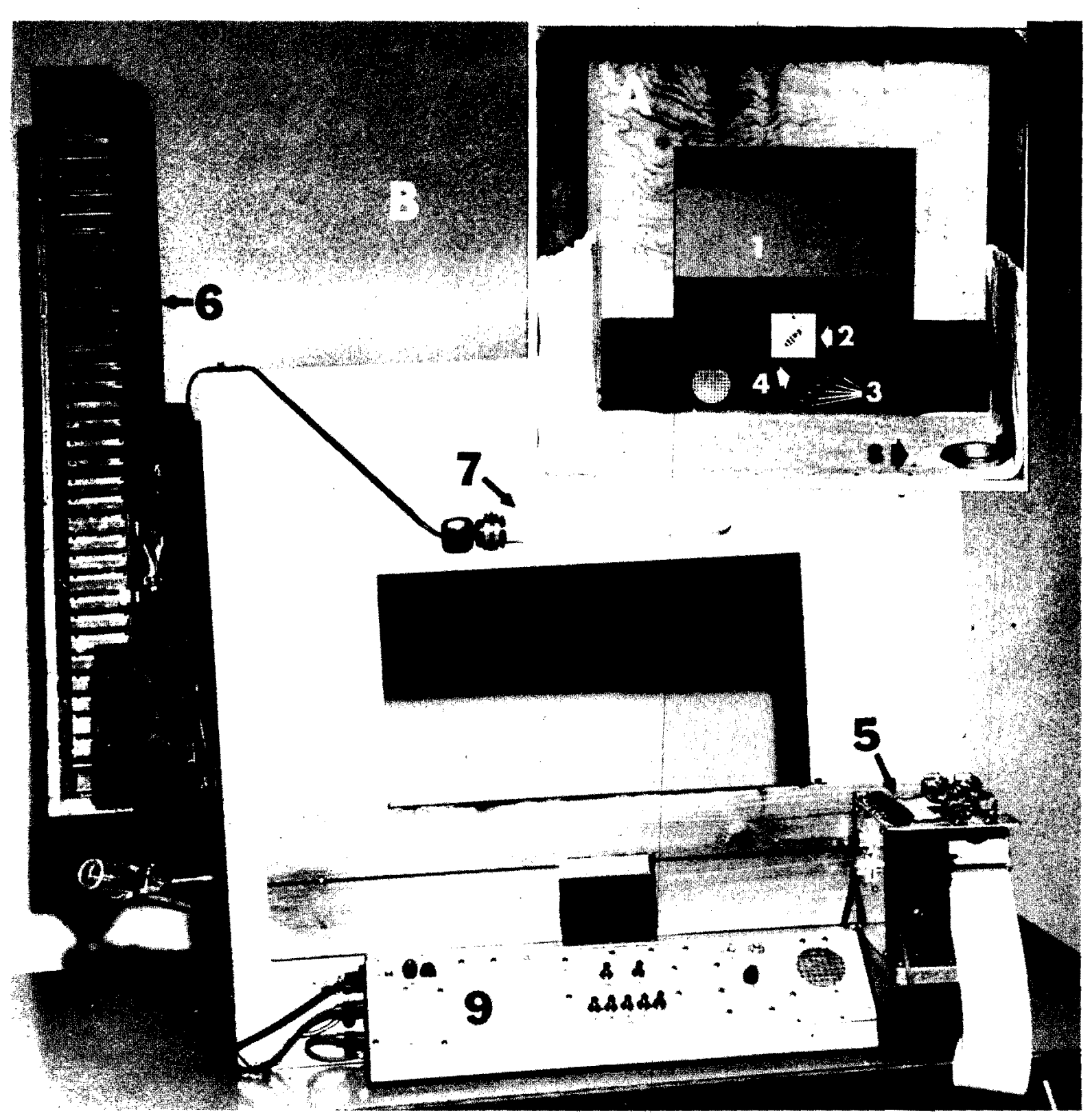

21

Figure 1. A. The interior of the booth, as viewed from the child's position. B. The booth as viewed from the experimenter's position. C. The control console.

1. Open window for experimenter. 4. Voice-activated neon tubes, 7. Overhead light.

2. Window for picture stimuli. 5. Event recorder. 8 . Dispenser tray.

3. Bank of five lights. 6 . Nutrient dispenser. 9 , Control console.

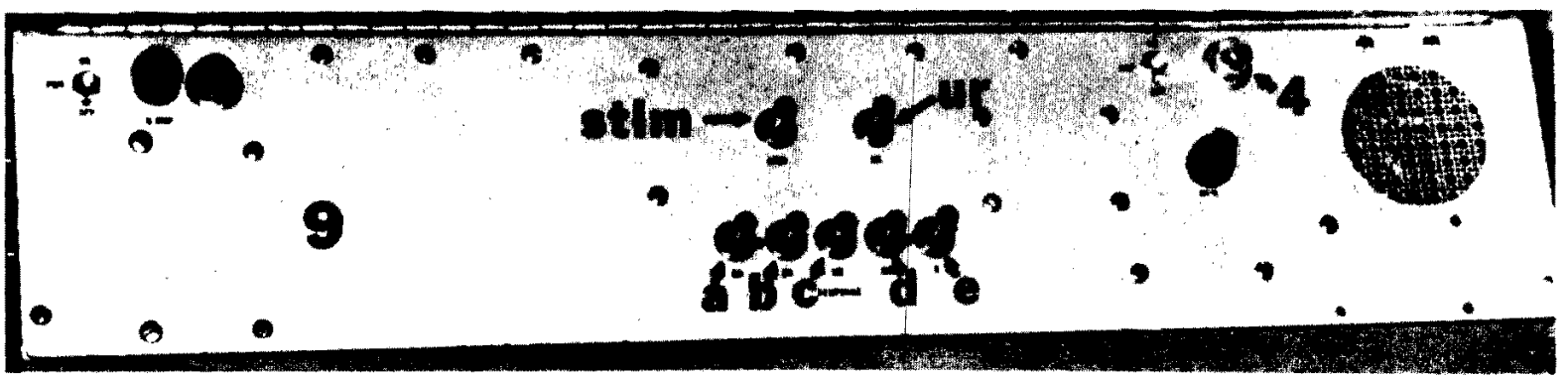


The experinental control hooth (Maurer, 1968) incouporated the following features (Fignye 1): (1) an opon windo: for the expeximenter; (2) a sma11 window for the subject; (3) a red light activated by the reinforcement switch and visible to the subject; (4) a Universal 70 bucket dispenser for nutrient reinforcements; (5) a dispensing tube assembly with receptacle tray; and (6) a console with reinforcement toggle switch.

\section{SELECTION OF STIMULI}

Stimuli for this investigation consisted of discrete two-second 500 and $4000 \mathrm{~Hz}$ pure tones delivered by earphone to the test ear at 70 dB HL. These frequencies were selected because they represent low and high frequencies normally included in both screening and threshold testing, thereby permitting greater generalization of results to certain aspects of standard audionetry.

A signal duration of two seconds was selected after consulting research reports on effect of duration of pure tone signals upon perceived threshold. Goldstein and kramer (1960) noted that most studies to that time had indicated that threshold would not be affected beyond approximately $150 \mathrm{msec}$. Wright (1960) summarized many studies and placed the reported limit at 200 msec. The comprehensive investigation carried out by Goldstein and Kramer reported diminishing effects by duration even beyond this, but indicated that threshold values for pure tones

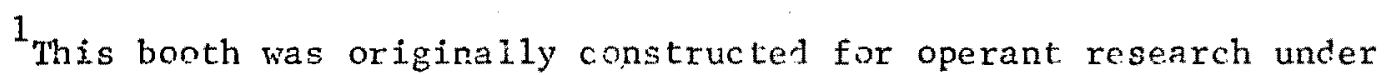
Public Health Research Grant 70-4382 by Research Instrument Service, University of Oregon Medicol School, Portland, Oregon. 
should not be expected to decrease significantly for signals of 2000 msec (two seconds) or longer.

\section{SELECTION OF REINFORCEMENTS}

Both social and tangible (nutrient) reinforcements were used on a $100 \%$ schedule. This was based on a study of 72 retarded children by Horowitz (1963), who reported that combined candy and verbal (sacial) reinforcement for vocal responses resulted in the greatest resistance to extinction, and that continuous reinforcement was inch more effective than partial (50\%) reinforcement in achieving stimulus control.

Selection of an appropriate nutrient reinfores for each child was accomplished in the following manner prior to actual experimental procedures. Each child was allowed to choose just one of five nutrient bits, each in a separate cup, which were offered on a tray. The specific nutrients were halved $M \& M$ candies, Cocoa Puffs, halved Crispy Critters, halved Froot Loops, and Trix. The item selected was then replenished and a second offering made. This procedure continued until one edible item had been chosen twice. That nutrient was then used as a tangible reinforcer with that particular child. Social reinforcement consisted of the experimenter's exclamations of "Fine," "Good," Excellent," etc., accompanied with a smile and/or nod. For purposes of this study, the term "reinforcement" will hereafter refer to cunbined social and tangible reinforcement.

\section{PROCEJURES}

Eanh child was subjected to twn mxferimontal treatments. In cadcr to negate effects of presentabium orote, the chiloiren were randomiy 
assigned to two groups: Group A children received Treatment one first; Group B children received Treatment Two first. Each subject was allowed a brief rest period between treatnents. During this time, he was taken from the test room by an assistant, this period allowing the experimenter to replenish the dispenser buckets with reinforcers.

Prior to exposure to either treatment, esch subject was preconditioned to a task-readiness stage, defined as (1) being seated before the experimental booth, and (2) having accepted piacement of the earphone over his test ear. The contralateral, non-test ear remained uncovered, that earphone resting anteriorly to the ear. This stage was achieved efther directly or by operant piocedures employing successive approximations.

- Response modes for each treatment were conditioned without the use of specific verbal instructions.

\section{Treatment One}

The child was conditioned lo drop a poker cinip into a pail immediately following presentation by earphone of a $70 \mathrm{~dB} 500 \mathrm{~Hz}$ pure tone signal of two seconds duration. Latency of each stimilus tone following the child's response, (or, if he did not respond, following the antecedent signa1), was randomized within one to ten seconds to avoid rhythming. Acquisition of stinulus control arbitrarily was considered complete when eight consecutive responses to the pure tones had occurred. A response without antecedent signal presentation resulted in no reinforcement and a delay of from 10 to 15 seconds before presentation of the next stimulus tone. 
Following acquisition of respone witerion, reinforcement terminated, but randomized stinuli presentations contimed either until extinction of responses was conplete or uncil. 25 cumulative unreinforced stinuli had been delivered. Ertjuction criterion was arbitrarily ciefined as failure to respond to $\mathrm{s}$ ix out of eight tonal stimuli. Identical procedures followed for acquisition and extinction of motor responses to the $4000 \mathrm{~Hz}$ signals, completing Treatment One.

\section{Treatment Two}

The child initially was conditioned to echo the experimenter's vocalizations in the following manner: If the child vocalized spontaneously during the initial two minutes following achievement of task readiness, the last syllable of his utterance was echoed by the experimenter. This sequence of child vocalization followed by experimenter echoing was reinforced and continued until eight consecutive sequences had been completed. The next reinforcement was then withheld, allowing the experimenter to initiate the subsequent sequence and to be echoed by the child. This reversed contingency was, thereafter, the only one reinforced through acquisition of criterion.

If no vocalizations were spontaneously emitted by the child during this brief initial period, the experimenter vocalized /a/ and simply waited for the child to imitate him. This contingency was reinforced until the criterion of eight consecutive responses by the subject was achieved.

Following acquisition to vocal stinuli, transfer to $500 \mathrm{~Hz}$ pure tone stimuli was achieved in the following marner: A continuous $500 \mathrm{~Hz}$ pure tone at $70 \mathrm{~dB}$ HL was introduced into the subject's test ear by 
earphone four seconds prior to each of the experimenter's stimulus vocalizations, and was continued tirrough the superimposed vocalization for another two seconds, both stimuli then terminating simultaneously. This contingency was repeated as necessary to achieve transfer of the $s^{D}$ properties of the experimenter's vocalizations to the pure tones. Randomized latencies for presentation were continued as before. The experimenter's vocalization was omitted from this contingency just as soon as the child responded to the pure tone; when the subject transferred his responses to the pure tone stimulus, pairing of the vocalization was terminated. In those cases in which transfer was more difficult, the experimenter gradually faded his vocalizations in intensity until only the pure tone stiniulus remained. In a few instances, it was necessary to reinstate these vocalizations one or more times in order to effect transfer. Acquisition was considered complete when the subject had made eight consecutive vocalization responses to pure tone stimuli.

Once criterion for pure tones was achieved, reinforcement was then. withheld, with the temporally randomized presentations of pure tone stinuli continuing again until either extinction, (failure to respond to six out of eight stimuli) or delivery of 25 cumulative unreinforced stimuli. Acquisition and extinction procedures then followed immediately with $4000 \mathrm{~Hz}$ tones. In those few cases in which vocal responses to $4000 \mathrm{~Hz}$ signals were not immediately acquired, the experimenter returned to vocal stimuli, achieved criterion, then paired the $11000 \mathrm{~Hz}$ signals with the vocal stimuli as necessary to effect transfer. 


\section{Chistis iY}

\section{RFSUES}

\section{GFNERAL}

Eleven of the originatly selected 14 subjects achieved the acquisition criteria for both treatments. One boy (DM) failed to achieve criterion for either 500 or $4000 \mathrm{~Hz}$ in Treatment 'Two, and one girl (LH) failed to achieve criterion on $4000 \mathrm{~Hz}$ only in 'Preatment One. One boy could not be adequately conditioned to the response tasks for either treatment and was dropped from the study. The latter was a 9-year Imonth-old boy with a Binet IQ of 42 and an MA of 2 years, 7 monchs. He had shown strong aversion to wearing carphones in previous attempts at audiologic assessment at Portland State University. In this investigation, extensive conditioning procedures were effective in bringing hin to hold one phone to his ear, and he responded appropriately to some signals. Because of the great anount of time required for conditioning, however, it was decided to exclude him from the study.

Treatment Two incorporates a conditioning procedure unusual to audiologic assessment of $M R$ children: response transfer from vocal to pure tone stimuli. The degree of difficulty in effecting response transfer with these subjects way be seen in Table III. Twelve of the 13 children sticceeded in achjeving the transfer criterion of eight consecutive responses to pure tone signals. One boy (Mi)) transferred to pure tones immediately, achieving criterion without need for any superimposed 
TABLE T.JI

DIFFICUTTY IN RESPONSE TRANSEER FOLLOWING

ACOUISITION TO VOCAT, STIMULUS

\begin{tabular}{|c|c|c|}
\hline Subjects & $\begin{array}{l}\text { No Combined Stimuli } \\
\text { Before Ist Response } \\
\text { to lonal stimulus }\end{array}$ & $\begin{array}{l}\text { No. Tonal Stimuli } \\
\text { Not Responded to } \\
\text { Before Acquisition }\end{array}$ \\
\hline \multicolumn{3}{|c|}{ Groun A } \\
\hline $\begin{array}{l}\mathrm{DB} \\
\mathrm{LH} \\
\mathrm{CB}(\mathrm{M}) \\
\mathrm{DM} \\
\mathrm{MD} \\
\mathrm{DS} \\
\mathrm{CB}(\mathrm{F})\end{array}$ & $\begin{array}{l}1 \\
9 \\
1 \\
7 \\
0 \\
2 \\
3\end{array}$ & $\begin{array}{c}1 \\
27 \\
5 \\
(43)^{a} \\
0 \\
0 \\
0\end{array}$ \\
\hline \multicolumn{3}{|c|}{ Group B } \\
\hline $\begin{array}{l}\mathrm{LK} \\
\mathrm{LL} \\
\mathrm{EH} \\
\mathrm{LD} \\
\mathrm{SH} \\
\mathrm{CC}\end{array}$ & $\begin{array}{r}4 \\
1 \\
1 \\
2 \\
20 \\
1\end{array}$ & $\begin{array}{r}0 \\
0 \\
0 \\
0 \\
19 \\
0\end{array}$ \\
\hline
\end{tabular}

add not achieve criterion; did not achieve transfer.

vocalizations by the experimenter. Five subjects (DB, CB-M, LL, EH and cc) required only one pairing of pure tone and vocal stimuli before they responded to the pure tone alone; two (DS and LD) required two pairings, another $(\mathrm{CB}-\mathrm{F})$ three, while EH ard $\mathrm{SH}$ needed 9 and 20 , respectively. The nean number of paired stimuit anong the 12 children who achieved transfer was 4.0; the range was 0 to 20. A t-test (see Appendix B) of the difference hetween the Group A mean, 3.385, and the Group B mean, 4.833, was not significant at the .05 level.

Anong the 12 children achieving transier, 8 responded to all consecutive pure tone stimuli following reinforcement of the first correct 
contingency. One girj. (IIi) fatlea to respond to just one tone, and one boy (CB-M) failed to respond to a total of 5 signals. Two gir $1 \mathrm{~s}$ (Lll and SH) achieved transfer with suctantial difficulty, failing to respond to 27 and 19 cumulative pure towes, respectively.

The subject who failed to ach seve transfer was a 15 -year-old boy with a recorjed Binet IQ of 37 , a score that falls just below the mean for the 9 childew for whom such data were available. This boy (DM) required 7 pairirgs of stimuli before his first response to an unpaired pure tone, and thereatter was unable to approach the transfer-acquisition criterion of 8 conscutive responses, with 43 cumulative failures to respond to pare ture signals.

It is of interest to note that $\mathrm{LH}, \mathrm{SH}$ and $\mathrm{DM}$ were among the oldest children in the sample, with the two girls representing the highest MA and IQ scores, respectively, (sce Table II) and that all three were very cooperative subjects.

Table IV reports on the subjects who did or did not extinguish for each frequency within the two treatments. It may be seen that only two subjects ( $D B$ and $M D)$ did not extinguish in either treatment, and that only one subject (EII) extinguished at both frequencies in both treatments. Of the 12 subjects who achieved criterion at both 500 and 4000 $\mathrm{Hz}$ in Treatment One, involving object dropping, 9 did not extinguish at either frequency. Two subjects ( $\mathrm{LH}$ and LI) extinguished on $500 \mathrm{~Hz}$ onIy, one (LH) failing to achieve criterion at $4000 \mathrm{~Hz}$.

In contrast, among the 12 subjects who acbieved criterion at both 500 and $4000 \mathrm{~Hz}$ in Treatment Two, involving EVR, only two did not extin-

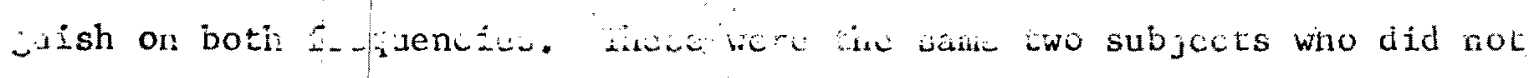
extinguish at either Érequency in Treatment One. All remaining subjects 
TABLE IV

SUBJECTS WHO EXTINGUISHED VS SUBJECTS

WHO DID NOT EXTINGUISH

\begin{tabular}{|c|c|c|c|c|}
\hline \multirow{2}{*}{ Subjects } & \multicolumn{2}{|c|}{ Treatment One } & \multicolumn{2}{|c|}{ Treatment Tho. } \\
\hline & $500 \mathrm{~Hz}$ & $4000 \mathrm{~Hz}$ & $500 \mathrm{~Hz}$ & $4000 \mathrm{~Hz}$ \\
\hline \multicolumn{5}{|c|}{ Group A } \\
\hline $\begin{array}{l}\mathrm{DB} \\
\mathrm{LH} \\
\mathrm{CB}(\mathrm{M}) \\
\mathrm{DM} \\
\mathrm{MD} \\
\mathrm{DS} \\
\mathrm{CB}(\mathrm{F})\end{array}$ & $\begin{array}{c}\text { DNE }^{a} \\
X^{b} \\
\text { DNE } \\
\text { DNE } \\
\text { DNE } \\
\text { DNE } \\
\text { DNE }\end{array}$ & $\begin{array}{l}\text { DNE } \\
(\mathrm{DNAC}) \mathrm{C} \\
\text { DNE } \\
\text { DNE } \\
\text { DNE } \\
\text { DNE } \\
\text { DNE }\end{array}$ & $\begin{array}{c}\text { DNE } \\
\mathrm{X} \\
\mathrm{X} \\
\text { (DNAC) } \\
\text { DNE } \\
\mathrm{X} \\
\mathrm{X}\end{array}$ & $\begin{array}{c}\text { DNE } \\
X \\
\mathbf{x} \\
\text { (DNAC) } \\
\text { DNE } \\
\text { DNE } \\
X\end{array}$ \\
\hline \multicolumn{5}{|c|}{ Group B } \\
\hline $\begin{array}{l}\text { LK } \\
\text { LL } \\
\text { EH } \\
\text { LD } \\
\text { SH } \\
\text { CC }\end{array}$ & $\begin{array}{c}\text { DNE } \\
X \\
X \\
X \\
\text { DNE } \\
\text { DNE }\end{array}$ & $\begin{array}{c}\text { DNE } \\
\text { DNE } \\
X \\
X \\
\text { DNE } \\
\text { DNE }\end{array}$ & $\begin{array}{l}X \\
X \\
X \\
X \\
X \\
X\end{array}$ & $\begin{array}{c}\mathbf{X} \\
\mathbf{X} \\
\mathbf{X} \\
\text { DNE } \\
\mathbf{X} \\
\mathbf{X}\end{array}$ \\
\hline
\end{tabular}

${ }^{a}$ Did not extinguish.

bextinguished.

cDid not achieve criterion.

except DS and LD, who failed to extinguish at just $4000 \mathrm{~Hz}$, extinguished for both frequencies in Treatment. Two. For the total group, there were 24 extinctions in 49 separate tests; i.e., extinction occurred in approximately $49 \%$ of the total rumber of tests naking up this study. Six of the 24 extinctions occurred in Ireatment one; the remaining 18 were in Treatment Two. Thus, Treatment one had a rate of extinction of $24 \%$, contributing $25 \%$ of the toial nurber of extinctions, while Treatment Two 
had an extinction rate of $75 \%$ and acoonted for $75 \%$ of the total number of extinctions.

\section{IT. ANATYBS OF THE DABA}

\section{Order of Treatment}

In order to determine whether crder of presentation of treatments was a significant factor in the findings, data were analyzed to determine whether the differeuces between neans of first and second presentaw tions were statistically significant. For this purpose, t-tests (see Appendix B) were applied to those differences anong the following data: (1) acquisition time to criterion; (2) number of tonal stimuli required to achieve criterion; (3) rates of correct response during extinction phase; and (4) rates of false response during the extinction phase. Examination of these data in Table $V$ shows that none of the t-tests reached the .05 level of significance. In terms of these data, order of presentation of trcatments was not a significant factor in this study. It is of interest, however, that Group A, which received Treatments one and Two in that order and included 25 tests, accounted for 8 extinctions, $1 / 3$ of the tota1, while Group $B$, which received the treatments in the reverse order and had 24 tests, accounted for 16 extinctions, or $2 / 3$ of the total.

\section{$500 \mathrm{~Hz}$ vs $4000 \mathrm{~Hz}$}

There would appear to be no basis for expecting substantial differences between means for 500 and $4000 \mathrm{lz}$, although procedures did adhere to a fixed order involving acquisition and extinction, with the low frequency signals first within each treatment. It was felt, however, 
TABLE V

COMPARISON OF MEANS FOR ORDER OF PRESENTATION

\begin{tabular}{|c|c|c|c|c|c|c|c|c|c|}
\hline \multirow{2}{*}{ Type of Data } & \multirow{2}{*}{ order } & \multicolumn{4}{|c|}{ Treatment One } & \multicolumn{4}{|c|}{ Treatment Twn } \\
\hline & & $500 \mathrm{~Hz}$ & $\mathrm{~N}$ & $4000 \mathrm{~Hz}$ & $N$ & $500 \mathrm{~Hz}$ & $\mathrm{~N}$ & $4000 \mathrm{~Hz}$ & $N$ \\
\hline $\begin{array}{c}\text { Mean acquisition } \\
\text { time to criterion } \\
\text { in seconds }\end{array}$ & $\begin{array}{l}\text { lst } \\
\text { 2nd }\end{array}$ & $\begin{array}{l}440.833 \\
225.333 \\
t=0.825^{a}\end{array}$ & $\begin{array}{l}6 \\
6\end{array}$ & $\begin{array}{l}110.60 \\
195.50 \\
t=1.991^{b}\end{array}$ & $\begin{array}{l}5 \\
6\end{array}$ & $\begin{array}{r}489.333 \\
446.667 \\
t=0.197\end{array}$ & $\frac{6}{6}$ & $\begin{array}{l}1.89 .667 \\
192.0 \\
t=0.02 .3\end{array}$ & $\begin{array}{l}6 \\
5\end{array}$ \\
\hline $\begin{array}{l}\text { Mean number of } \\
\text { tonul etimuli to } \\
\text { achieve crjterion }\end{array}$ & $\begin{array}{l}1 s t \\
\text { 2nd }\end{array}$ & $\begin{aligned} & 16.50 \\
& 11.333 \\
t & =1.162\end{aligned}$ & $\frac{6}{6}$ & $\begin{array}{c}9.20 \\
10.167 \\
t=0.423\end{array}$ & $\begin{array}{l}5 \\
6\end{array}$ & $\begin{aligned} & 14.0 \\
& 19.167 \\
+ & 0.407\end{aligned}$ & $\frac{6}{5}$ & $\begin{array}{l}13.0 \\
\vdots 1.60 \\
t=0.382\end{array}$ & $\begin{array}{l}5 \\
5\end{array}$ \\
\hline $\begin{array}{l}\text { Maan rate of } \\
\text { correct response } \\
\text { during extinction }\end{array}$ & $\begin{array}{l}\text { Ist } \\
\text { 2nd }\end{array}$ & $\begin{array}{r}4.289 \\
2.803 \\
t=1.622\end{array}$ & $\begin{array}{l}6 \\
6\end{array}$ & $\begin{array}{r}4.353 \\
3.424 \\
=0.806\end{array}$ & $\frac{5}{6}$ & $\begin{array}{r}2.144 \\
4.252 \\
t=1.719\end{array}$ & $\begin{array}{l}6 \\
6\end{array}$ & $\begin{array}{r}2.285 \\
t=1.163 \\
=1.679\end{array}$ & 6 \\
\hline $\begin{array}{l}\text { Mean rate of } \\
\text { false response } \\
\text { during extinction }\end{array}$ & $\begin{array}{l}\text { lst } \\
\text { 2nd }\end{array}$ & $\begin{array}{r}0.835 \\
0.424 \\
=0.765\end{array}$ & $\begin{array}{l}6 \\
6\end{array}$ & $\begin{array}{r}1.735 \\
1.037 \\
t=0.549\end{array}$ & $\frac{5}{6}$ & $\begin{array}{r}0.417 \\
0.024 \\
=0.912\end{array}$ & $\frac{6}{6}$ & $\begin{array}{r}0.737 \\
0.1 .17 \\
t=0.373\end{array}$ & $\begin{array}{l}6 \\
6\end{array}$ \\
\hline
\end{tabular}

${ }^{2}$ Levels of significance when both $\mathrm{Ns}$ equal 6 are 2.228 at .05 and 3.169 at .01 .

$b_{\text {Leveis of }} \mathrm{significance}$ when $N$ s are 5 and 6 are 2.262 at .05 and 3.250 at .01 .

Number of correct responses divided by time in seconds and multiplied by 60 equals rate of correct: response per minute.

$\mathrm{a}_{\text {Number }}$ of false responses (responses without antecedent signal tones) divided by time in seconds and multiplied by 60 equals rate of false response per minute. 
that this expectation of non-significance ought to be tested. Therefore, $t$-tests (see Appendix B) were applled to the differences between means for these two frequencies. Examinaticn of Table VI shows that all iscores are below the .05 level of signiflcance. Thus, neither the results for echoic nor motoric response modes appears to have been influenced by the frequency of the pure tone stimuli.

TABIE VI

COMPARISON OF MEANS FOR 500 AND $4000 \mathrm{~Hz}$ PURE TONES

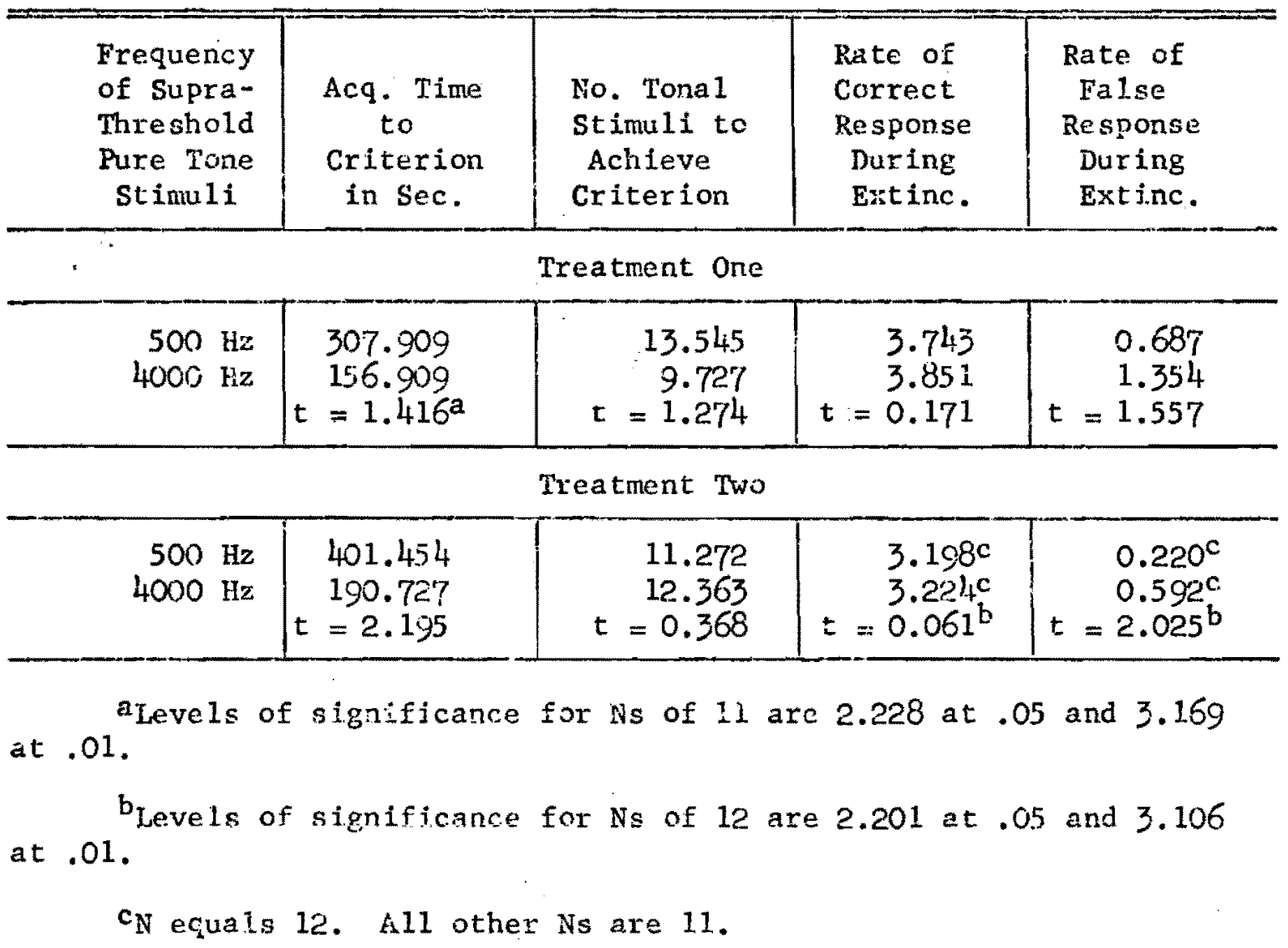

Ireatment One vs Treatment Two

T-tests were then applied to differences between means for Treatwent One and Titatment Two on line same data. Inspection of lable vil 
TABLE VII

COMPARISON OF MEANS OF TREATMENT ONE AND TREATMENT TWO

\begin{tabular}{l|c|c|c|c|c}
\hline & $\begin{array}{c}\text { Acq. Time } \\
\text { to } \\
\text { Criterion } \\
\text { in Sec. }\end{array}$ & $\begin{array}{c}\text { No. Tonal. } \\
\text { Stimuli to } \\
\text { Achieve } \\
\text { Criterion }\end{array}$ & $\begin{array}{l}\text { Rate of } \\
\text { Correct } \\
\text { Response } \\
\text { During } \\
\text { Extinc. }\end{array}$ & $\begin{array}{c}\text { Rate of } \\
\text { False } \\
\text { Response } \\
\text { During } \\
\text { Extinc. }\end{array}$ \\
\hline
\end{tabular}

${ }^{a}$ Levels of significance when $N$ are 12 are 2.201 at .05 and 3.106 at $: 01$.

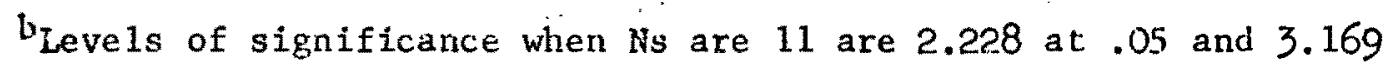
at .01 .

reveals that all t-scores are well below the .05 level of significance. It should be noted that acquisition times for Treatment Two include the response transfer from vocai to tonal stimuli, and that despite slightiy greater means in Treatment Two for both acquisition time and number of tonal stimuli to criterion, the differences are still not significant. In other words, in this heterogenous sample of MR children, with verbal instructions ruled out in each treatment, it did not require significantly more tine to condition echoic vocal responses, despite the response transfer stage, than it did to conditiun standard motor responses. Although $t$-scores for the differences between means of acquisition and extinction data for the two treatments did not achieve a level of 
statistical significance (see Tabie VII), two trends are apparent in the extinction phase. One is that somewhat more ialse responses (responses without an antecedent signal tone) occurred in Treatment One than in Treatment Two. Although there was considerable disparity in the distribution of the sample, the modn number of false responses for object dropping (Treatment one, both frequencies) during the extinction phase was 8.75 , while the nean number of false responses for EVR (Treatment Two, both frequencies) was only :.C 6 . Despite this trend, a t-test of the difference between these means, as for previously reported extinction data, did not achieve the .05 level of significance.

The second trend has previously been referred to: there was three times as much extinction in Treatment Two (EVR) as in Treatnent one (object dropping). Although the extinction data did rot achieve a statistical leve1 of significance, this trend is most apparent in Figures 2 and 3 , comparing cumulative response curves for the two treatments,

\section{Leve 1 III vs MI Leve1 IV}

Although the number of subjects who could clearly be differentiated by psychometric data was limited, t-tests were applied to differences between means of subjects in MI Level III (moderate ratardation) and MI Level IV (severe retardation). Results of these statistical treatments are seen in Table VIII. The only significant difference occurred at 500 $\mathrm{Hz}$ in Treatment One on number of tonal stimuli to achieve criterion, and this was at the .05 level only. In this instance, the number of stimuli was greater for 4 severely retarded children than for 5 moderately retarded subjects. No significant differences vere found between MI III and MI TV children in any other frequency-treatment combination. 


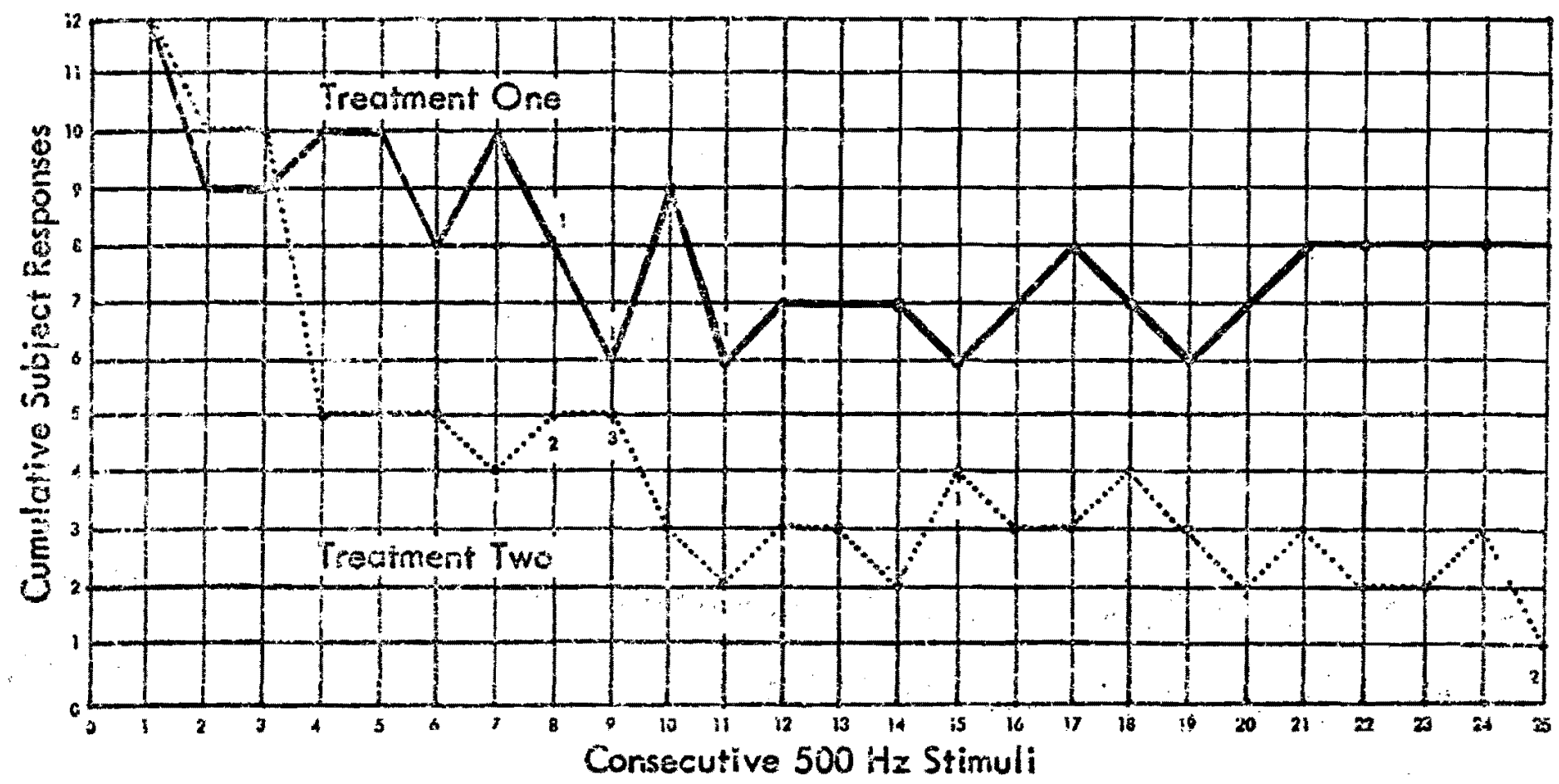

Figure 2. Comparison of cumulative response curves for Treatment One (object dropping) and Treatment Two (EVR) during extinction phase for $500 \mathrm{~Hz}$ stimuli following withdrawal of reinforcement. (Numbers refer to subjects achioving extinction criterion). 


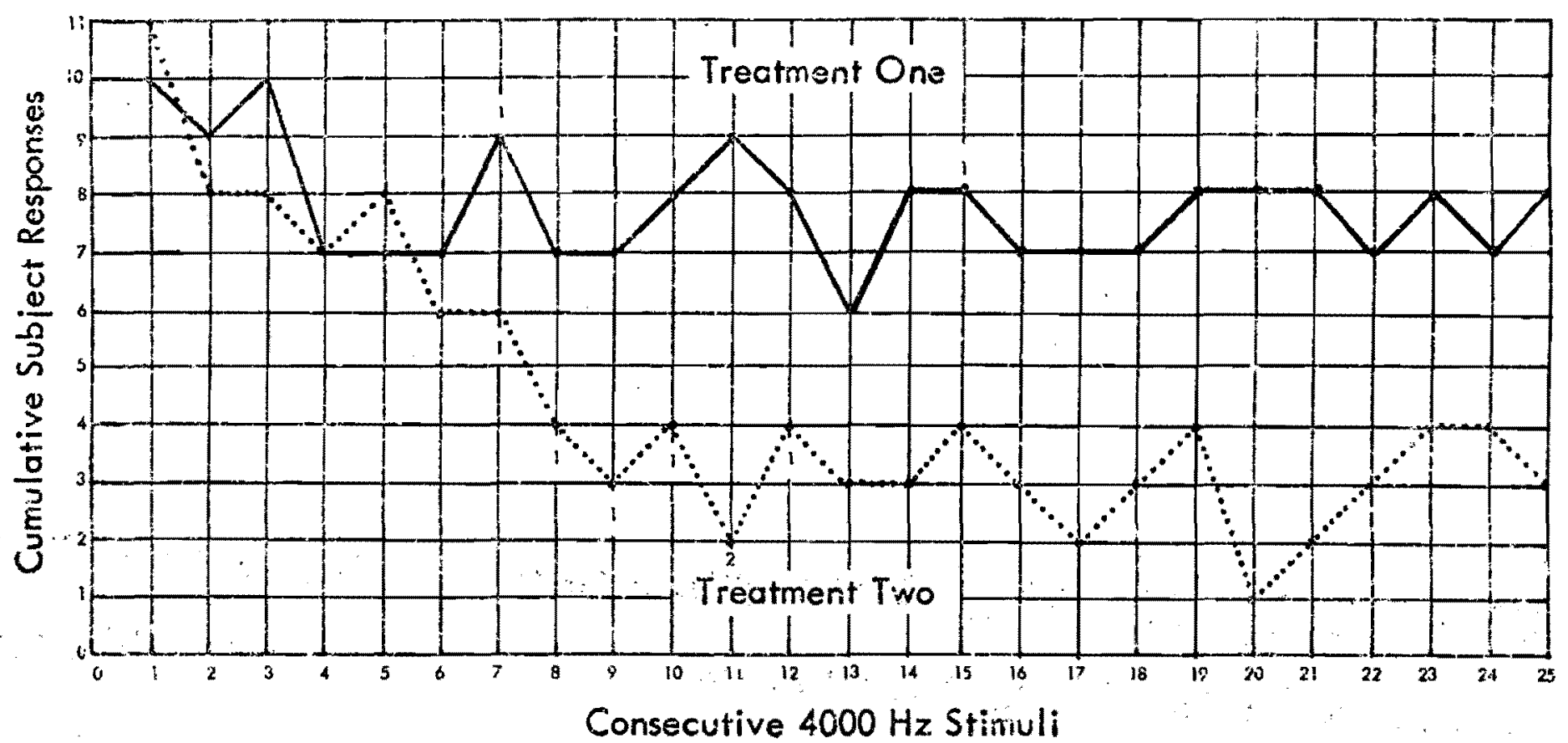

Figure 3. Comparison of cumulative response curves for Trearment One (object dropping) and Treatmeni Two (EVR) during extinetion phase for $4000 \mathrm{~Hz}$ stimuli following withdrawal of reinforcement. (Numbers refer to subjects achieving extinction criterion). a

aNote that Figures 2 and 3 account for only 17 of the 18 extinctions occurring in Treat ment iwo. Since subject $\mathrm{LH}$ did not achieve criterion at $4000 \mathrm{~Hz}$ in Treatment One (see Table IV), her responses for both treatments at that frequency, and her extinction at that frequency in Treatment Two, were excluded from Figure 3. 
IABTE VIIS

COMPARISON OF MEANS OF MI LVVEL III AND MI LEVEL IV

\begin{tabular}{|c|c|c|c}
\hline Acq. Time & No. Tonal & Rate of & Rate of \\
to & Stimuli to & Response & False \\
Criterion & Achieve & During & Desponse \\
in Sec. & Criterion & "Extinc." & "Extinc," \\
\hline
\end{tabular}

Treatment one

\begin{tabular}{|c|c|c|c|c|c|}
\hline 500 & $\begin{array}{l}\mathrm{Hz}: \\
\mathrm{MI} \text { III } \\
\text { MI IV }\end{array}$ & $\begin{array}{l}210.0^{a} \\
602.5 \\
t=1.845^{b}\end{array}$ & $\begin{array}{c}10.0^{\mathrm{a}} \\
22.25 \\
\mathrm{t}=3.082\end{array}$ & $\begin{aligned} & 3.518^{a} \\
& 4.090 \\
t= & 0.370\end{aligned}$ & $\begin{array}{r}0.109^{a} \\
0.138 \\
t=0.185\end{array}$ \\
\hline 4000 & $\begin{array}{l}\mathrm{Hz}: \\
\mathrm{MI} \text { III } \\
\mathrm{MI} \text { IV }\end{array}$ & $\begin{array}{l}177.0 \\
121.25 \\
t=0.981^{c}\end{array}$ & $\begin{array}{r}44.0 \\
32.0 \\
t=1.0\end{array}$ & $\begin{array}{r}4.115 \\
5.406 \\
t=0.793\end{array}$ & $\begin{aligned} & 0.0 \\
& 0.294 \\
t= & 0.390\end{aligned}$ \\
\hline
\end{tabular}

Treatment Two

\begin{tabular}{|c|c|c|c|c|c|}
\hline 500 & $\begin{array}{l}\mathrm{Hz}: \\
\text { MI III } \\
\text { MI IV }\end{array}$ & $\begin{array}{l}790.0 \\
271.25 \\
t=2.115\end{array}$ & $\begin{aligned} 33.75 \\
8.0 \\
t=1.594\end{aligned}$ & $\begin{array}{r}3.007 \\
3.736 \\
t=0.463\end{array}$ & $\begin{aligned} & 0.625 \\
& 0.0 \\
t= & 1.0\end{aligned}$ \\
\hline 4000 & $\begin{array}{l}\mathrm{Hz}: \\
\mathrm{MI} \text { III } \\
\mathrm{MI} \cdot \mathrm{IV}\end{array}$ & $\begin{array}{r}150.75 \\
168.75 \\
t=0.275\end{array}$ & $\begin{array}{c}13.0 \\
12.5 \\
t=0.123\end{array}$ & $\begin{array}{r}2.922 \\
3.579 \\
t=0.454\end{array}$ & $\begin{array}{r}1.105 \\
0.088 \\
t=0.917\end{array}$ \\
\hline
\end{tabular}

${ }^{a} \mathrm{~N}$ equals 5 . All other ivs are 4.

${ }^{b}$ Levels of significance when $N s$ are 4 and 5 are 2.365 at .05 and 3.499 at .01 .

cievels of significance when both Ns are 4 are 2.447 at .05 and 3.707 at .01 .

Relation of IQ. MA and CA to Acquisition and Extinctica Data

Product-moment correlations (see Apfendix B) were computed between

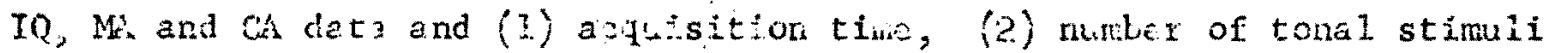
to acquisition, (3) rate of correct response duxing extinction phase, 
and (4) rate of false response during extinction phase. Computations for each frequency-treatment combination resulted in a total of 48 coefficients of correlation. Table IX illustrates that these $\boldsymbol{r}_{\mathrm{s}}$ were quite inconsistent. Overall, correlations were equally divided between positive and negative. Approximately $69 \%$ of these were either negligible or slight, $27 \%$ were substantive, with only about $4 \%$ showing a high degree of

TABLE IX

FREQUENCY OF POSITIVE AND NEGATIVE CORREIATIONS BETKEEN IQs, MA, CAs AND ACQUISITION-EXTINCTION DATA

\begin{tabular}{|c|c|c|c|c|c|c|c|}
\hline \multirow[b]{3}{*}{ Range of $\mathbf{r}$} & \multicolumn{6}{|c|}{ Parameters Correlated } & \multirow[b]{3}{*}{ Totals } \\
\hline & \multicolumn{2}{|c|}{ IQ } & \multicolumn{2}{|c|}{ MA } & \multicolumn{2}{|c|}{$\mathrm{CA}$} & \\
\hline & Acq. ${ }^{a}$ & Ext: & Acq. & Ext. & Acq. & Ext. & \\
\hline .00 to .20 & $\begin{array}{l}+0 \\
-1\end{array}$ & $\begin{array}{l}+0 \\
-3\end{array}$ & $\begin{array}{l}+2 \\
-1\end{array}$ & $\begin{array}{l}+1 \\
-4\end{array}$ & $\begin{array}{l}+1 \\
-1\end{array}$ & $\begin{array}{l}+0 \\
\cdot 2\end{array}$ & $\begin{array}{l}+4 \\
-12\end{array}$ \\
\hline .20 to .40 & $\begin{array}{l}+4 \\
-1\end{array}$ & $\begin{array}{l}+1 \\
-0\end{array}$ & $\begin{array}{l}+1 \\
-1\end{array}$ & $\begin{array}{l}+1 \\
-0\end{array}$ & $\begin{array}{l}+2 \\
-1\end{array}$ & $\begin{array}{l}+1 \\
-4\end{array}$ & $\begin{array}{l}+10 \\
-\quad 7\end{array}$ \\
\hline .40 to .70 & $\begin{array}{l}+1 \\
-1\end{array}$ & $\begin{array}{l}+2 \\
-2\end{array}$ & $\begin{array}{l}+2 \\
-0\end{array}$ & $\begin{array}{l}+1 \\
-0\end{array}$ & $\begin{array}{l}+2 \\
-1\end{array}$ & $\begin{array}{l}+1 \\
-0\end{array}$ & $\begin{array}{l}9 \\
+\quad 4\end{array}$ \\
\hline .70 to 1.0 & $\begin{array}{l}+0 \\
-0\end{array}$ & $\begin{array}{l}+0 \\
-0\end{array}$ & $\begin{array}{l}+1 \\
-0\end{array}$ & $\begin{array}{l}+0 \\
-1\end{array}$ & $\begin{array}{l}+0 \\
-0\end{array}$ & $\begin{array}{l}+0 \\
-0\end{array}$ & $\begin{array}{l}+1 \\
-\quad 1\end{array}$ \\
\hline Totals & $\begin{array}{l}+5 \\
-3\end{array}$ & $\begin{array}{l}+3 \\
-5\end{array}$ & $\begin{array}{l}+6 \\
-2\end{array}$ & $\begin{array}{l}+3 \\
-5\end{array}$ & $\begin{array}{l}+5 \\
-3\end{array}$ & $\begin{array}{l}+2 \\
-6\end{array}$ & $\begin{array}{l}+24 \\
-24\end{array}$ \\
\hline
\end{tabular}

a"Acquisition" here refers to both acquisitjon time and number of stimuli to criterion.

b"Extinction" here refers to both rate of correct response and rate of false response during extinction as defined in this study. 
relationship. There was no instance in which a substantial (.40 to .70) or high (above.70) correlation was clearly supported by sinilar frequencytreatment pairings, and in many cases there was direct contradiction in terms of positive versus negative relationship. It is clear that in this small, heterogenous sample of retarder children, in which IO and MA ranges varied only 19 points and 1 year, 7 months, respectively, and in which Ns for psychometrically-measurea subjects were only 7 and 9 , that there was no consiscent relationship between IQ, $M A$ or $C A$ nin the one hand, and acquisition and extinction data on the other.

\section{SUMMARY OF RESULTS}

\section{Acquisition}

(1) Eleven of the original 14 mentally retarded subjects achieved acquisition criteria for both treatments, i.e., for both EVR and motor response modes.

(2) Response transfer fxom vocal to pure tune stinuliz was accomplished with little difficulty with 10 of the 13 subjects exposed to it. Two girls achieved transfer with substantial difficulty, and one boy failed to achieve transfer.

(3) Acquisition data did not differ significantly between treatments for the retarded children in this study.

\section{Extinction}

(1) Extinction following withdrawal of reinforcement occurred in 24 of the 49 separate tests comprising this study.

(2) Three times as much extinction cccuxred with EVR in Ireatment Two than with object dropping in Treatment One. Six extinctions occurred 
in Treatment One; 18 extinctions occurred in Treatment Two. Nine of the 12 subjects in Treatment one did not extinguish at either frequency; only 2 of the 12 subjects in Treatment Two diu not extinguish at either frequency.

(3) There was a trend toward more false responses in Treatment one (object dropping) as compared with Treatment Two (EVR).

(4) Differences in extinction data between the two treatments were not statistically significant in terms of rate of correct response, rate of false response, and number of false responses up to the point of achievement of extinction criterion.

\section{Order of Treatments}

(1) order of presentation of treatments was not a significant factor in terms of acquisition time, number of toral stimuli to acquisition, rate of correct response during the extinction phase, or rate of false response during extinction phase.

(2) Eight extinctions anong 25 tests occurred. in Group A, which received Treatment One first. Sixteen extinctions occurred among the 24 tests of Group B, which received Treatment Two first. Thus, Group A accounted for $1 / 3$ of the extinctions, while Group $B$ accounted for $2 / 3$.

\section{Additiona1 Results}

(1) Frequency of the pure tone stimuli (500 vs $4000 \mathrm{~Hz}$ ) was not a significant factor in the results.

(2) Among the small numbers of subjects who could be categorized on the basis of psychometric sata, no clear and consistent differences were fcum in slatistical analysis of acquisition and extinction data 
between MI level III (moderately retarded) and MI Levei IV (severeiy retarded) children.

(3). The snal1 numbers of subjects on whorn specific $M A$ and IQ scores were avaliable, and the relacively small numerical ranges encompassed, did not permit consistent, meaningful correlations of psychometric data with acquisition and extinction data. 


\section{CHAPTER $V$}

\section{DISCUSSION}

Results reported in the preceding chapter demonstrate no significant differences in acquisition data between object dropping and EVR. Thus, the first hypothesis of this study is not supporited by the results. However, it is interesting that the additional procedures of vocal conditioning and response transfer in Treatment Two did not require a significantly greater amount of time than the simpler procedures of ireatment One. Since verbal instructions were not used in conditioning either response node, this raises the question as to whether EVk could be effected in less time with such assistance. If the subject could be directly conditioned to EVR for pure tones with the he1p of verbal instruction, then it is conceivable that this response mode might be acquired significantly faster than object dropping. This, however, remains to be established.

The difficulty in icsponse transfer encountered by three subjects, (two finally achieving it ard one failing after many stimuli pairings), and their general characteristics, (cooperative, among the oldest, one near the IQ mean, the other two at the top of the respective $M A$ and IR ranges), is interesting. The boy (DM) who failed to achieve transfer was in Group A, in which Treatment One was presented first. He had easily acquired criterion for object drcpping responses with the minjmum number of tonal stimn! and had not cutinguisined at either frequency. in was a iso in Group A, bui iad iten $x$ riatively siow to achjeve object 
dropping criterion for $500 \mathrm{~Hz}$, subsequently extinguishing, and had failed to achieve criterion at $4000 \mathrm{~Hz}, \mathrm{SH}$, however, was a Croup B subject who went on to achieve criterion at both frequencies in Treatment One rather quickly without extinguishing for either. These three subjects do not appear to share any characteristics which would distinguish them from their peers except age and the psychometric data referred to. Consequently, the question arises as to whether age is an influencing factor 1n response transfer among retardates. This should be the object of further study.

The second hypothesis of this study tends to be supported in terms of the substantially greater nunber of extinctions occurring in associaticn with EVR as compared to object dropping, a ratio of three to one. Evidently, for the retarded bildren in this saniple, resistance to extinction was greate: for object dzupping than for echoic vocalizing. This raises the question as to whether EVR might be made more resistant to extinction in some manner. One possibility involves utilization of the voice-activated neon tube in the experimental control booth (see Figure 1). This was not in operation for this study. A future application in which activation of this ligint by a vocal response is made contingent upon an antecedent test tone should be investigated.

The trend toward occurrence of fewer false responses for EVR than object drcppirg also deserves some future consideration. There appeared to be nore dispersal of this phenomenon among the subjects engaged in object dropping than when they respondcd vocally. The false responses associated with EVR, while sometimes numerous, were 1 imited to fewer children. Tf this is a trend which is suctained ir future studies, then 


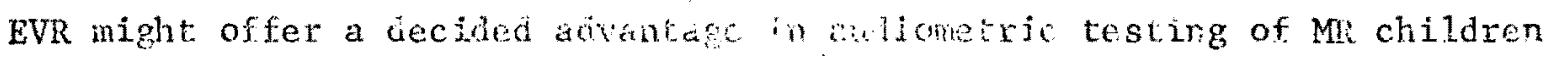
prone to demonstra:e a lith frecutey of fajse positive notur responses. The greater froqueary of uxin in anong Group $B$ subjects--16 in 24 tests-as compared with govp a subjechs, who had only 8 in 25 tests, is felt to te a chance cocurrerce waties than if function of order of treatments. There is no evidence that onder of presentation was a significant factor in the obtained results, and there is no rationale wich would seem to support a relationship between that factor and extinction. Similarly, it would seem that little or no weight ought to be attached to the one significant $t$-score (at the .05 level) found between means for number of tonal stimuii to criterion at $500 \mathrm{~Hz}$ in Treatment One between MI Level III and MI Jeve 1 IV childrem. The Ns of 5 , the absence of significant t-scores for any other froquency-treatment acquisition data, the limited ranges for psychometric data, and the subsequent inconsistent $r$ s betwcen psychometric and acquisition-extinction data lend support to this position.

The results provide ro initial evidence to suggest that echoic vocalization would be impractical as a response mode for routine audiologic assessment of certain mentally retarded or other subjects. Indeed, the findings tend to support the position that it may be a useful adjunct to the audiologist's options, Certainly, one can think of some physically handicapped patients, retarded and otherwise, for whon a response mode other than object dropping or hand raising might be desirable. The applicability of EVR to clinical threshold determination, however, remains to be estahlished.

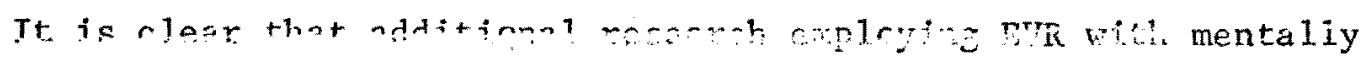
retarded children is neederi. It is jeit that the following questions and 
proposals merit serious coubideration:

(1) Can verbal instruction be used in conjunction with operant techniques to effectively bypass the rocal conditioning and response transfer stages used in this study to achieve $k \mathrm{~g} k$ ? This would entail verbally directing the subject. to vocalize a syllable such as /a/ inmediately following perception of each pure tone signal and reinforcing this contingency to achieve stimulus control. Certainlj, an investigation of this question should he intiated. If it is established that EVR can be directly conditioned among MRs, then this nodification should be compared with a similarly verbal-assisted object dropping response mode.

(2) If response transfer is shown to be essential to EVR among $M$ children, then an investigation limited to that procedure should compare older and younger retardates sharing sinilar MAs in order to determine whether the older children tend to be more resistant to transfer.

(3) The possibility of increasing the resistance to extinction for EVR among MR children by use of a voice-activated light should be. $\operatorname{explored.}$

(4) Frequency of false positive response in EVR as compared to object dropping should be an integral part of any further research.

(5) FVR and object dropping should be compared for effectiveness in threshold determination among $M R$ children. This is an essential stop toward clinical application of this response node.

(6) Pairing of motor and EVR modes jn testing MR or other difficult-to-test pationts should be investigated. Of particular interest are (a) whether a combination of the two response modes would result in greatar resistance to extincticn then aither oie slone, and (b) whather 
valid responses might be separable from false positive responses on the basis of pairing vs absence of pairing.

(7) Other applications of breath expulsion or inspiration as response modes should be explored. It is conceivabie that blowing a whistle or horn might prove to be practical and less resistant to extinction than phonation. Audible inspiration of breath might also be an effective response mode for some children if it could be brought under stimulus control. This phenomenon has been observed to sometimes precede a motor response to a sound stimulus among young children. 
CHAPTER VI

SUMMARY AIND CONCIUSTONS

\section{PKOBLEM}

Nentally zetarded children demonstrate an abrormaly high incidence of hearing impairment, and many, particularly those with rọs below 40 , are difficult for audiologists to test. Consequently, there is great need among this population for investigating response modes and conditioning of responses to auditory stimuli. A review of the literature reveals no studies of echoic vocalization as a conditioned response node to pure tone stimuli among the retarded.

\section{METHOD}

A heterogenous sample of 13 moderately and severely mentally retarded children ranging in age from 7 years, 7 months to 16 years, 3 months were compared on two response modes to suprathreshold pure tone signals of 500 and $4000 \mathrm{~Hz}$ : (1) dropping poker chips, and (2) echoic vocalization (EVR). All subjects received both treatments, but were divided into Groups $A$ and $B$, the former receiving Treatment one (object dropping) first, the latter receiving Treatment Two (EVR) first. Operant procedures combined social and tangible reinforcement in each treatment to achieve stimulus control without specific verbal instructions. EVR in Treatment Two included two umisual stages: (1) conditioning of imitations to the experinenter's single-syllable vosalizations, usualiy /a/, and 
conditioning of response transfer fron vocal to pure tone stimuli. Acquisition and extinction to first 500 and then $4000 \mathrm{~Hz}$ proceeded sequentially within each treatment. Acquisition criterion for both vocal and pure tone stimuli was arbitrarily defined as eight consecutive responses. Extinction was arbitrarily defined as failure to respond to six out of eight tonal stimuli following withdrawal of reinforcement.

\section{RESULTS}

(1) Eleven of the 13 children achieved acquisition criterion for both response modes.

(2) Three of the 13 children encountered stbstantial difficulty in response transfei.

(3) Acquisition data for the two treatments did not differ significantly.

(4) Extinction occurred anong slightly less than half of the subjects. EVR in Treatment One accounted for three times as much extinction as object dropping in Treatment one.

(5) There was a trend toward greater occurrence of false responses in Treatment one (object dropping) as compared with Treatment Two (EVR).

(6) Up to achievement of extinction criterion, differences in extinction phase data between treatments were not statistically significant.

(7) Order of presentation of treatments was not a significant factor in the results.

(8) More extinction occurred in Group $B$ than in Group A. This was attributed to a chance occurrence. 
(9) Frequency of the pure tone stinuli was not a significant fartor in the resules.

(10) No clear, consistent differences were found between moderately retarded and severely retarded subjects, but is for those with valid psychoneiric data were smali and ranges of scores were limited.

(11) No consistent relationship between MA, IQ, and CA data on the one hand, and acquisition-oxtinction data on the other vas evident in the results.

\section{CONCLUSIONS}

Despite substantially greater frequency of extinction following withdiawal of rejuforcement as compared with object dropping, echoic vocalization response (EVR) has been shown to be an effective and practical response mode to suprathreshold pure tone stimuli among a small, heterogenous sample of moderateiy and severely nentally retarded children.

Further investigations in clinical and experimental settings are recommended and described. 


\section{REFERENCES}

Barr, Bengt, Pure tone audionetry for preschool children. Aata otolaryng., Suppi. 1? 1 (1955).

Beedle, R. K., Webb, C. E., Kinde, S. W., and Weber, B. A., A behavior observation technique of screening hearing of instirutionalized mentally retarded children. Amer. I. ment. Defic., $70,675-82$ (1966).

Birch, J. W., and Matthews, J., The hearing of mental defertives: its neasurenent and characteristics. Amer. J. ment. Defic., 55, 384$93(1.951)$.

Bradley, E., Evans, W. E., and Worthington, A. M., The relationship between administration time for audiometric testing and the mental. ability of mentally deficient children. Amer.J. ment. Defic., 60, $3+6-53(1955)$.

Curry, E. T., and Kurtzrock, G. H., A preliminary investigation of the ear-choice technique in threshold audiometry. J. Speech Hearing Dis., 16, 240-45 (1951).

Das, J. P., Acquisition and extinction of verbal conditioned responses in mental defectives. Psychologia Kyoto, 4, 209-13 (1961).

Eagles, $\overrightarrow{\mathbf{x}_{1}}$. L., and Doerfler, L. G., Hearing in children: acoustic envi.ronment and audioneter performance. I. Speech Hearing Bes., if, $149-63(1961)$

Ewing, A. W. G., Aphasia in Children. London: Oxford Medical Publica-tion $(1930)$.

Ewing, J. R., and Ewing, A. W. G., The ascertainment of deafness in infancy and early childhood. I. Laryng. Otol., 52, 309-33 (1944).

Fisch, L., Auditory problens in mentally retarded children. Folia Fhoniat., 20, 122-32 (1968).

Foale, M., and Paterson, J. N., The hearjing of mental defectives. Amer: J. ment. Desic., 59, 254-58 (1954).

Frisina, D. R., Meastrenent of hearing in children. In J. Jerger, (Ed.),

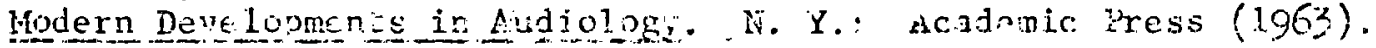

Frisina, D. R., and T1nyd, T, r., Dianission of underlying fiotors re.* lated to the audiologic espects of mental retardation. In $L$. L. 
Lloyd and D. R. Frisira, (Eds.), The Audiologic Assessment of the Menta11y Retarded: Proseedings of a National Conference. Parsons, Kansas: Speech and Hearing Dept., Parsons State Hospital and Training Center (1965a).

Frisina, D. R., and Lloyd, L. L., Surmary and conclusions. In I. L. Lioyd and D. R. Frisinc, (Lds.), The tudiologic Assessment of the Mentally Retarded: Proceedings of a National Conference. Parsons, Kansas: Speech and Hearing Dept., Parsons State Hospital and Training Center (1965b).

Froesche1s, E., and Beebe, H., Testing hearing of newborn infants. Arch. Otolaryng., 44, 710-14 (1946).

Fulton, R. T., A review: GSK audiometry with the mentally retarded. In L. L. Lloyd and D. R. Frisina, (Eds.), The Audiologic Assessment of the Mentally Retarded: Proceedings of a National Conference. Parsons, Kansas: Speech and Hearing Dept, Parsons state Hospical and Training Center (1965).

Fulton, R. T., and Graham, J. T., Conditioned orientation reflex audiometry with the mental1y retarded. Amer. J.ment. Defic.: 70, $703-08$ (1966).

Fulton, R. T., and Lloyd, L. L., Hearing impairment in a population of children with Down's syudrome. Amer. J. ment. Defic., 73, 298302 (1968).

Gardner, J. W., President's Comnittee on Mental Retardation, A First Report. Wn., D. C.: U. S. Government Printing office, 0-269-237 (1967).

Garrett, H. E., Statistics in Psychology and Education. N. Y.: Longmans, Green and Co. (1953).

Garwood, V. P., Current trends in EEG audiometry. In L. L. Lloyd and D. R. Frisina, (Eds.), The Audiologic tssessment of the Mentally Retarded: Proceedings of a National Conference. Parsons, Kansas: speech and Hearing Dept., Parsons State Hospital and Training Center (1965).

Goldstein, R., Special audiometric tests: their educationaI signifirance. Amer. Ann. Ded. 107, 481-89 (1962).

Goldstein, R.: and Kramer, J. C., Factors affecting thresholds for short tones. J. Speeth Hearing Re:3., 2, 249-5E (1960).

lleber, R., A manual on terminology and classification in mental retardation. Amer. I. ment. Defiz.. Monogr. Supp 3. (1959).

Heber, R., Modifications in the manual on terminology and classification in mental retardation. Amer. J. ment. Defic., 65, 499-500 (1961). 
Hirsh, I. J., The Measurement of Hearing. N. Y.: McGraw-Hill (1952).

Horowizz, F. N., I. Partial and continuovs lefiforcement of vocal responses using candy, vocal, and smiling reinforcers among retardates. In F. L. Darley, (t.), Language studies of menta1ly retarded children, J. Speach Hearing Dis. Monogr. Suppl. No. 10, $55-69(10,63)$.

Kerr, N., Meyerson, I., and Michael, J., A procedure for shaping vocalizations in a mute child. In L. P. Ullman and I. Krasner, (Eds.), Case studies in Behavior Modification. N. Y.: Holt, Rinehart and Winston (1965).

Kimmich, H. M., Otologic aspects of mental retardation: implications for diagnostic audiology: In L. L. Lloyd and D. R. Frisina, (Eds.), The Audiologic Assessment of the Mentally Retarded: Proceedings of a Nationa 1 Conference. Parsons, Kansas: Speech and Hearing Dept, Parsons State Hospital and Training Center (1965).

Kodman, Frank, Jr., Powers, T. R., Weller, G. M., and Philip, P. P., Pure Tone audionetry with the mentally retarded. Except. Child., 24, 303-05 (1958).

Kopatic, N. J., The reliability of pure tone audiometry with the mentaj.1y retarder: soine practice 1 and theoreticel considerations. Train. Sch. Bu11., 60, 130-36 (1953).

La Crosse, E. L., and Bidlake, H., A method tu test the hearing of mentaliy retarded chiluren, volca Rev., 66, 27-30 (196\%).

Ladefoged, P., Elements of Acoustic Phonetics. Univ. of Cilicago Press $(1962)$.

Lamb, N. I.., and Grahan, J. T., GSR audiometry with mentally retarded adult nales. Amer. I. ment. Defic., 72, 721-27 (1968).

Leach, E., Introduction to the Parsons Demonstration Project in Speech Pathology and Audiology. Ir L. L. Lloyd and D. R. Frisina, (Eds.), The Audiologic Assessment of the Menta11y Retarded: Proceedings of a National Conference. Farsons, Kansas: Speech and Hearing Dept., Farsons State Fospital and Trainjing Center (1965).

Lillywhite, H. S., and Bradley, D. P., Communication Problems in Menta1 Retardation: Diagnosis and Management. N. Y.: Harper \& Row (1969).

Lloyd, L. L., Behavioral audionetry viewed as an operant procedure. J. Speech Hearing Dis., 31, 128-35 (1966).

Lloyd, L. L., Comparisons of selected auditory measures on mentally retarded children: a preliminary report. In L. L. Lloyd and $D$. k. Frisina, (Eds.), the Audiologic Assessment of the Mentally Retarded: Proceedings of a National Conference. Parsons, 
Kansas: Speech and Hearing Dept., Parsons State Hospital and Training Center (1.965a).

Lloyd, L. L., Use of the slide show audionetric technique with mentally retarded children. Except. Child., 32, 93-98 (1965b).

Lloyd, L. L., and Frisine, D. R., (Eòs.), The Audiologjc Assessment of the Mentally Retarded: Proceedings of a National Conference. Parsons, Kancas: Spescin and Hearing Dept., Parsons State Hospital and Training Center (1965a).

Lloyd, L. i.., and Frisira, D. R., Introduction to the March Conference. In L. I. Lloyd and D. R. Frisina, (Eds.), The Audiologic Assessment of the Mentalli Retarded: Procedings of a National Conference. Parsons, Kansas: Speech and Hearing Dept., Parsons State Hospital and Training Cenier (1965b).

Lloyd, I. L., and Melrose, J., Reliability of selected auditory responses of normal hearing mentally retarded children. Amer. J. ment. Defic., $71,133-43$ (1966).

Lloyd, L. L., and Reid, M. J., The reliability of speech audiometry with institutionalized retarded children. J. Speech Hearing Res., 2, 450-55 (1966).

Lloyd, L. L., Reid, M. J., and McNanis, D. L., Pure tone reliability of a clinical sample of institutionalized MR children. Amer. J. ment. Defic., $73,279-82$ (1968).

Lloyd, L. L., Spradlin, J. E., and Reid, M. J., An operant audiometric procedure for difficult-to-test patients. J. Speech Hearing Dis., 23, 236-45 (1968).

Maurer, J. F., Sustaining and shaping vocal behavior in pre-lingually deaf pre-school children. Unpublished Ph. D. dissertation, University of Oregon (1968).

Mende1, M. I., Infant responses to recorded sounds. J. Speech hearing Res., 11, 811-16 (1968).

Meyerson, L., Hearing for speech in children: a verbal andiometric test. Acta Otolaryng. Supp1, 128 (1956).

Meyerson, L., Pathways to the future in the audiological assessment of the mentally retarded.- In L. L. l.hoyd and D. R. Frisina, (Eds.), The Audiologic Assessment of the Mentally Retarded: Froceedings of a Natjonal Conference. Farsoirs, Kansas: Speech and Hearing Dept., Parsons Stato Hospital and Training Center (1965).

Meyerson, I., and Michae 1, J. I., The Measurenent of Sensory Thresholds in Exceptiona1 Children: An Experimental Approach to Some Prohlems of Differenciai Diagnosis and Education With Reference to 
Hearing. Coop. Res. Project No. 418. Houston, Tex.: liniv. of Houston, May $3:(1950)$.

Miller, J., de Schweinit?, i., "and Gotzinger, C. P., How infants three, four and five month of age respond to sound. Exceft. Child., 30, $149-54$ (1963).

Nudo, L. A., Comparison by age of audjolnginal and otological findingo in a state residential institution for the mentally retarded: a preliminary report. In L. L: Iloyd and D. R. Frisina, (Eds.), The Audiologic Assessment of the Mentally Retarded: Froceedings of a National Conference. Parsons, Kansas: Speech and Hearing Dept., Parsons State Hospita1 and Training Center (1965).

0'Nei11, J. J., and Oyer, H. J., Applied Audiometry. N. Y.: Dodd, Mead and Co. (1966).

Reynolds, G. S., A Primer of Operant Conditioning. Glenview, I11.: Scott, Foresman and Co. (1968).

Rheingold, H. L., Gewirtz, J.: L., and Ross, H. W., Social conditioning of vocalizations in the infant. J. comp. Hhysiol. Psychol., 52, $68-73(1359)$.

Ryan, M. Don, and Stewart, J. H., The use of textured pictures as a reinforcement in meaningful sound identification audiometry. In L. L. Lloyd and D. R. Frisina, (Eds.), The Audiologic Assessment of the Mentally Rëtarcied: Froceedings of a National Conference. Parsons, Kansas: speech and Hearing Dept., Parsons state Hospita1 and Training School (1965).

Salzinger, K., Feldman, R. S., Cowan, J. E., and Sa1zinger, S., operant conditioning of verbal behavior of two young speech-deficient boys. In L. Krasner and L., P. Ullman, (Eds.), Research in Behavior Modification. N. Y.: Holt, Rinehart and Winston (1968).

Schlanger, B. B., and Gottsleben, R. H., Testing the hearing of the mentally retarded. J. Speech Hearing Dis., 21, 487-93 (1956).

Spradiin, J. E., Procedures for evaluating processes associated with receptive and expressive language. In R. I. Schiefelbusch, R. H. Copeland, and J. O. Smith, (Eds.), Language and Mental Retardation. N. Y.: Rinehart \& Winston (1967).

Spradlin, J. E., and Lloyd, I. L., Dperant conditioning audiometry (OCA) with low level. retardates: a preliminary report. In L. L. Lloyd and D. R. Frisina, (Eds.), The Audiologic Assesszient of the Hental1y Retarded: Froceedings of a National Conference. Farsors, Kansas: Speech and lfearing Dept, Farsons State Hospital and Training Center (1065).

Suzuki, T., and Ogiba, Y., Conditioned orientation reflex audiometry. Arrh. Otolaryn., 74, 192.98 (196:). 


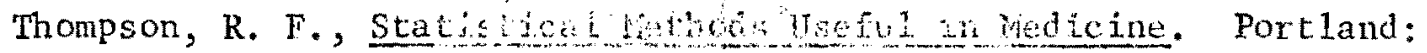
Univ. of Oregon Jorkel Bchor, Depl. of Eublic Health and Preventive Medicine $(1065)$.

Waldon, E. F., Testing of hisans: jnplicarions for audiomeflexometry. In L. L. Lloyd and 1), R. Fisire, (Eds.), The Andiologic Assessment of the Mentally Metared: zrocedings of a National conference. Parsons, Kansis: Speoh and learing Dept.; Parsons state Hospital and Training Conter $(1965)$.

Weaver, R. M., The use of filmstrip stories in slide show audiometry. In L. L. Lloyd and D. R. Trisina, (Eds.), The Audiologic Assessment of the Mentally Retarded: Froceedings of a National Conference. parsons, Kansas: speech and Hearing Dept.. Parsons state Hospital and J'raining Centor (1965).

Webb, C. B., Kinde, S. W., Weber, B. A., and Beedle, R. K., Incidence of hearing loss in institutionelized mental retardates. Amer. J. ment. Defic., 70, 563-68 (1966).

Webb, c. E., Kinje, S. W., Weber, B.:A., and Beedle, R. K., Procedures for Evaluating the Hearing of the Mentally Retarded. U. S. Office of Educ. Coop. Research Project No. 1731, Jan. (1964).

Weber, E. W., Mentally Retarded Children and Their Education, Springfieid, I11.: Charles C, Thomas (1963).

Webster's New Collegiate Dictionary. Springfie1d, Mass.: G. \& C. Merriam Co. (1959).

Wright, H. N., Measurement of perstimulatory auditory adaptation. I. acoust. Soc.Amej, $32,1558-67$ (1960). 


\section{APPENDIX A}

\section{DEFINITION OF TECHNICAL TERMS AND ABBREVIATIONS}

\section{AUDIOLOGIC TERMS}

dB: The abbreviation for the term decibel, which is $1 / 10$ of a bel.

The decibel expresses the ratio of two values of pover. It is a useful measure for comparing the power of two sounds.

HL: The abbreviation for the term hearing level or hearing loss, which is the deviation from the established threshold level represented by a zerc reading on the hearing loss dial of the audiometer.

Hz: The abbreviation for the term Hertz, from the German physicist, Heinrich Hertz, about 1886. It is equivalent to cycles par second (cps), referring to the number of double sine waves or complete cycles cccurring in a vibrating body each second.

Masking: The amount by which the threshold of audibility of a sound is raised by the presence of another (masking) sound. The unit customarily used is the decibel $(d B)$.

Pure tone: A simple tone or sound wave, the instantaneous sound pressure of which is a simple sirusajdal function of the time.

Screening (audiometric): A method or group of methods designed to separate individuals wose thresholds lie above the normal from those whose thresholds iie at or below the normal threshold. Both speech and pure tones are 1 ised as test signals.

Sourd Eje1d: A region containing sound waves. Sund field audionetric iesting introduces either pure tone or speech signals to the subject by means of alr conducted sound waves without the use of earphones or cone oscillater, usually within a confined room espectally desighed for that purpose.

SPL: The abbreviation for the term sound prassure level, which is, in decibels, 20 times the logarithm to the base 10 of the ratio of the pressure of tlits sound to the reference pressure, usually stated as .0002 dynes per $\mathrm{cm}^{2}$.

Suprathreshold: Above threshold; i.e., a sotind stimulus which is above tne tinreshold for hearing. 
Threshold testing: Determination of the lawest intensity of a stimulus required to produce a sensation in a subject or elicit a response from hin.

\section{OPERANT TERMS}

Discriminative stimulus $\left(\underline{S}^{D}\right)$ : A stimulus in whose presence a particular bit of operant behavior is highly probable, because the behavior has previously been reinforced in the presence of that stimulus.

Neutral stimulus $(\underline{\Delta})$ : Any environnertal event which at any particular time brings about no change at all in behavior, whether it precedes, accompanies, or follows a response.

operant conditioning: The science of behaviox in which the frequency of occurrence of bits of behavior is modified by the consequences of the behavior.

Paradigrm: A model or pattern.

Reinforcement theory: Operant conditioning thenry.

Stimulus control: The stage in operant conditioning at which an $s^{D}$ will, with a high degree of probability, control a particular cperant (response). The high frequency of the operant in the presence of the $\mathrm{SD}^{D}$ is achieved through the frequent accompaniment of the sil with the occurrence of the operant and subsequent reinforcement of this contingency.

Stimulus generalization: The tendency to respond to other stimuli in addition to the one stimulus in the presence of which the resporse was first reinforced. An organism or behavicr is said to generalize to all those stimuli in whose presence the rate of responding increases after the response has been reinforced in the presence of one other stimulus. 
APFENDIX B

FORMULAE USED FOR STATISTICAI COMPUTATIONS

I. T-TESTS

When the number of scores was the same for both groups:

$$
t=\frac{\bar{x}_{1}-\bar{x}_{2}}{\sqrt{\frac{\Sigma x_{1}^{2}-\left(\Sigma x_{1}\right)^{2} / N+\Sigma x_{2}^{2}-\left(\Sigma x_{2}\right)^{2} / N}{N(N-1)}}}
$$

When the number of scores for each group was rot equal:

$$
t=\frac{\bar{x}_{1}-\bar{x}_{2}}{\sqrt{\frac{\Sigma x_{1}^{2}-\left(\Sigma x_{1}\right)^{2} / N_{1}+\Sigma_{1}^{2}-\left(\Sigma x_{2}\right)^{2} / N_{2}\left[\frac{1}{N_{1}} \frac{1}{N_{2}}\right]}{\left[N_{1}-N_{2}-2\right]}}}
$$

$N$ refers to the number of subjects; $\mathrm{X}$ represents the scores for each parameter; and $\bar{X}$ equals the respective sample means. (Thompson, 1965). 
When comparison of neans for two measures nas nade on the same subjects for both treatiments:

$$
t=\frac{\bar{x}_{2}-\bar{x}_{1}}{\sqrt{\frac{5 D^{2}-(s D)^{2} / N}{N(N-1)}}}
$$

$\overline{\mathrm{X}}$ represents the respective mean; $\mathrm{D}$ refers to deviations of each subject on the two parameters; and $N$ is the nuraber of pairs of scores (Thompson, F. 33).

\section{COFFFICILNTS OF CORRELATION}

Product-ucriont formula:

$$
r=\frac{N X Y-\Sigma X \Sigma Y}{\sqrt[8]{\left[N X^{2}-(\Sigma X)^{2}\right]\left[N Y^{2}-(\Sigma Y)^{2}\right]}}
$$

$N$ refers to the number of subjects; and $\mathrm{X}$ and $\mathrm{Y}$ refresent the acoues or valuas, respectively, whose linear relationship was investigated (Thompson). 